\title{
ROMANIZACIÓN Y CONSUMO: CAMBIOS Y CONTINUIDADES EN LOS CONTEXTOS CERÁMICOS DE HISPALIS EN ÉPOCAS TURDETANA Y ROMANO-REPUBLICANA
}

\section{ROMANIZATION AND CONSUMPTION: CHANGES AND CONTINUITIES IN THE CERAMIC CONTEXTS OF HISPALI IN TURDETAN AND ROMAN REPUBLICAN PERIODS}

\author{
ENRIQUE A. GARCÍA VARGAS \\ FRANCISCO J. GARCÍA FERNÁNDEZ*
}

\begin{abstract}
Resumen: Con este trabajo intentamos describir y explicar los cambios que se aprecian en los repertorios cerámicos de Hispalis (Sevilla) entre los siglos III y I a.C. como reflejo de las transformaciones en los hábitos alimenticios y en las pautas de consumo de las poblaciones del Bajo Guadalquivir a finales de la Edad del Hierro y durante los primeros siglos de la ocupación romana. Para ello se revisarán los diferentes contextos de ocupación de época turdetana y romano-republicana documentados en las excavaciones llevadas a cabo en la ciudad de Sevilla. A continuación se analizarán las producciones cerámicas locales y su evolución, así como las novedades tipológicas procedentes tanto del ámbito púnico como del itálico, tanto en lo que se refiere a los recipientes de transporte como especialmente a los de cocina y al servicio de mesa. Para terminar, se llevará a cabo una reconstrucción diacrónica de todo el proceso desde finales del siglo IV a.C. hasta el cambio de Era.

Palabras claves: Hispalis (Sevilla), romanización, cerámica, cocina, alimentación, consumo.
\end{abstract}

Las novedades aportadas en los últimos años por la arqueología sevillana, especialmente en lo que se refiere a los contextos de época romano-republicana, afectan tanto a la cronología de los niveles de ocupación como a la caracterización funcional y cultural de

* Este trabajo ha sido realizado en el marco de los proyectos "Sociedad y Paisaje. Economía rural y consumo urbano en el sur de la Península Ibérica (Siglos VIII a.C. - II d.C.)", financiado por el Ministerio de Ciencia e Innovación (HAR2008-05635/HIST); "Repensando Tartesos bajo el prisma de la identidad: el componente
Abstract: In this paper, we attempt to describe and explain the changes detected in the pottery repertoires of Hispalis (Seville) between the $3^{\text {rd }}$ and $1^{\text {st }}$ centuries $\mathrm{BC}$ as a reflection of the transformation of the eating habits and patterns of consumption of the people of the Lower Guadalquivir in the Late Iron Age and early centuries of the Roman occupation. For this purpose, we shall review the different contexts of Turdetanian and Roman-Republican occupation documented in the excavations carried out in the city of Seville. Secondly, we shall analyse the local pottery products and their evolution, and the typological novelties introduced from both the Punic and the Italic spheres, with particular focus on the vessels used in transport and, especially, in cooking and serving at the table. Finally, we offer a diachronic reconstruction of the whole process from the late $4^{\text {th }}$ century to the change of Era.

Key words: Hispalis (Seville), Romanization, pottery, cooking, food, consumption.

los repertorios cerámicos a ellos asociados. Esto supone una oportunidad para profundizar en el estudio de este periodo y adentrarnos en determinadas cuestiones hasta ahora inéditas, debido a la ausencia de documentación, como son los procesos de interacción,

fenicio", financiado por el Ministerio de Educación y Ciencia (HUM2007-63419/Hist) y "La construcción y evolución de las entidades étnicas en Andalucía en la Antigüedad (siglos VII a.C.- II d.C)", Proyecto de Excelencia financiado por la Consejería de Innovación, Ciencia y Empresa de la Junta de Andalucía (HUM-3482). 
asimilación y transformación de las comunidades locales, y también las foráneas, durante los primeros siglos de la presencia romana. Dichos procesos se manifiestan de forma especialmente clara en la evolución de los contextos de consumo, no sólo en lo referido a la evolución de la vajilla doméstica, sino también a los hábitos alimenticios asociados a su uso. A ello habría que unir, lógicamente, la llegada de productos importados, a través del análisis de la procedencia y distribución de los recipientes anfóricos.

No obstante habrá que aclarar qué entendemos por caracterización funcional y cultural. No creemos que la vajilla cerámica, así como otros elementos de la cultura material, puedan servir por sí solos de guía para rastrear grupos étnicos. Generalmente se trata de recipientes que trascienden fácilmente las fronteras étnicas de recipientes y sociales debido a su función utilitaria. Incluso en el caso en que los objetos en cuestión sean portadores de un mensaje o una ideología (por ejemplo, la cerámica griega de figuras negras o figuras rojas), éste siempre será reinterpretado por la comunidad receptora en base a sus propios parámetros mentales, necesidades o aspiraciones. No obstante, las variaciones en los repertorios cerámicos, vistos en su conjunto, la aparición de nuevos recipientes y nuevos usos relacionados tanto con la preparación de alimentos como con el consumo -ritualizado o no-de determinados productos puede reflejar cambios en los hábitos de consumo que en el fondo estén indicando una transformación sustancial en la matriz cultural o incluso étnica.

En este sentido cabe especular sobre el papel de la cerámica, en general (ánforas, vajilla de mesa, menaje de cocina, etc.), como indicador de formas de preparación y consumo (Bats 1988). En las páginas que siguen presentamos una primera aproximación al tema a partir de los repertorios documentados en la ciudad de Sevilla. Partiremos de la contextualización estratigráfica del material cerámico (apartado 1), para analizar a continuación el repertorio formal de tradición local, sus trasformaciones a lo largo del tiempo y las novedades tipológicas de origen púnico e itálico (apartados 2 a 4), concluyendo con un ensayo de evolución formal de las distintas familias entre fines del siglo IV y fines del I a.C. (apartado 5).

\section{LA BASE DOCUMENTAL: SECUENCIAS ESTRATIGRÁFICAS DE LA SEVILLA PRERROMANA Y ROMANO-REPUBLICANA}

En los últimos años el número de intervenciones arqueológicas realizadas en la ciudad de Sevilla se ha incrementado súbitamente, lo que ha proporcionado una ingente cantidad de información sobre sus etapas históricas, especialmente en lo que respecta a la estructura y organización de la trama urbana (Beltrán y otros 2005; González Acuña 2005). No obstante, la dilatada y compleja historia de la ciudad ha dificultado enormemente el estudio de sus fases más antiguas, sobre todo las anteriores al periodo imperial romano. La potencia estratigráfica de la secuencia ocupacional, en ocasiones de más de ocho metros, la escasa profundidad a la que aparece el manto freático, así como el reducido tamaño de los cortes impide por lo general registrar contextos anteriores al cambio de Era. A ello habría que añadir la metodología empleada en algunas excavaciones, que imposibilita la individualización de niveles de uso, sobre todo pavimentos o depósitos relacionados con la construcción o amortización de expedientes constructivos (García y González 2007: 527-528; García Vargas 2009: 437-464; García Fernández 2009).

Recogemos aquí las secuencias que han proporcionado una información más nítida sobre el periodo que nos ocupa (fig. 1), así como los contextos materiales más amplios y completos para analizar los cambios, a nivel morfológico y funcional, de los repertorios cerámicos desde finales del siglo IV a.C. hasta el tránsito al siglo I d.C. ${ }^{1}$

Cuesta del Rosario esquina con calle Galindos (2012) ${ }^{2}$

El sondeo realizado por F. Collantes de Terán en 1944 en la Cuesta del Rosario (Collantes de Terán 1977) puede, con todas sus limitaciones metodológicas, ser considerado como la primera estratigrafía arqueológica llevada a cabo en Sevilla. A pesar del notorio trabajo de catalogación y revisión de M. Vera (1987) y J.J. Ventura (1985), el valor de sus materiales cerámicos como referente crono-tipológico para el estudio de la romanización en la ciudad es hoy día limitado. El motivo es, fundamentalmente, la falta de una contextualización estratigráfica clara de los mismos, contextualización que sí es posible para los materiales

1. Este trabajo se inserta dentro de un proyecto más amplio cuya finalidad es el estudio del fenómeno urbano en la ciudad de Sevilla, desde sus orígenes hasta finales de la Antigüedad, a través del análisis de los contextos arqueológicos relacionados con actividades de ocupación (domésticos, industriales, funerarios, públicos, etc.) y de los repertorios materiales a ellos asociados. En él participan, además de los que suscriben, de D. González Acuña, J. Vázquez Paz, J. Beltrán Fortes y S. Ordóñez Agulla.

2. Número de registro, correspondiente al código asignado a las excavaciones durante el proceso de revisión de las estratigrafías y los materiales llevado a cabo en el Museo Arqueológico de Sevilla entre septiembre de 2004 y diciembre de 2005. 


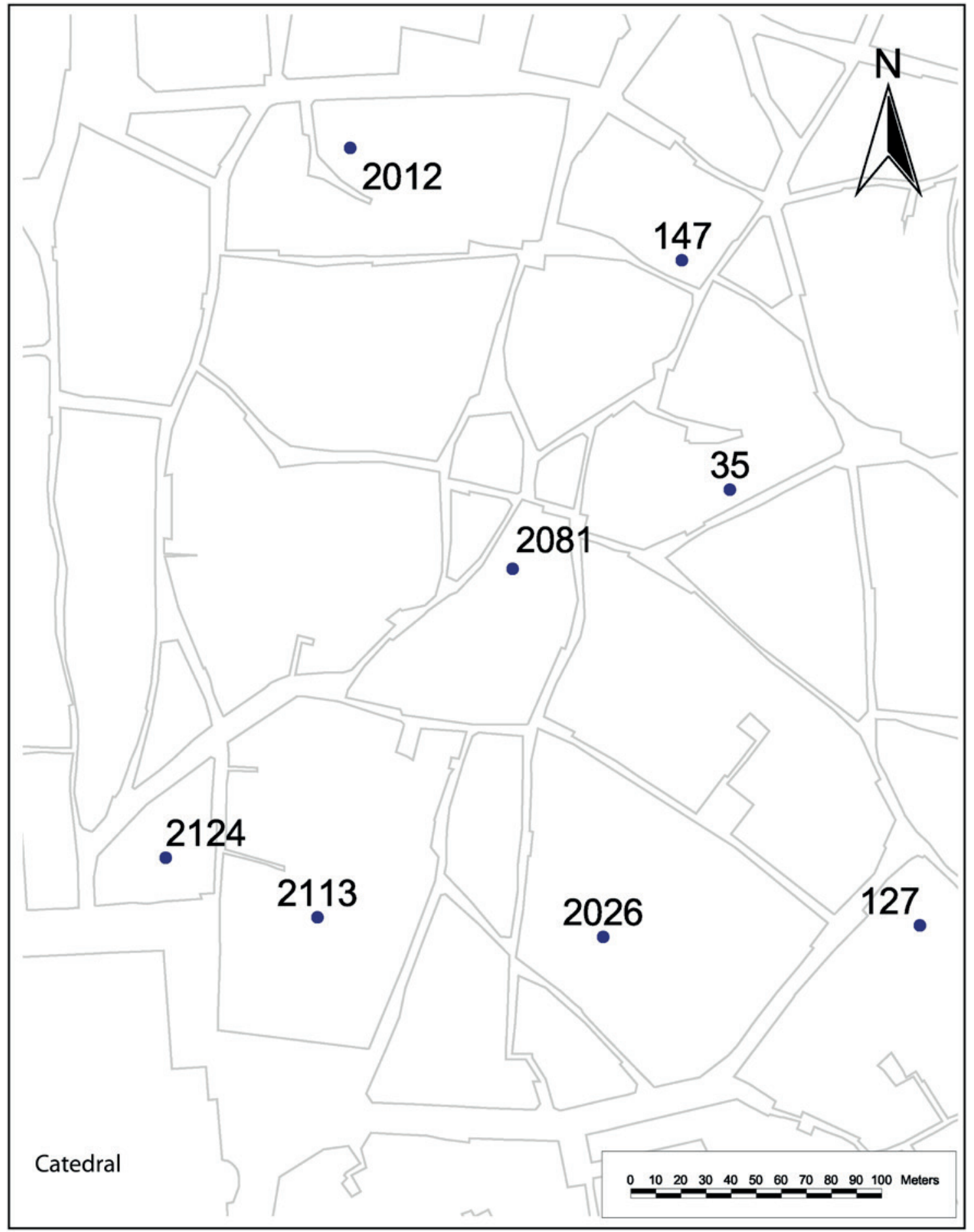

Figura 1. Excavaciones arqueológicas revisadas y su distribución sobre el parcelario actual del centro histórico de Sevilla. 
contemporáneos del resto de las intervenciones que se analizan en este trabajo, lo que nos permite hacer descansar sobre estos últimos la mayor parte de nuestras conclusiones. No obstante, la periodización de $\mathrm{M}$. Vera es, con alguna matización al respecto de las fechas $^{3}$, sustancialmente acertada, siendo este particular, el carácter aparentemente ininterrumpido de la secuencia estratigráfica (reconstruida) ${ }^{4}$, la riqueza de los materiales, su similitud con los documentados en otras excavaciones -especialmente en Argote de Molina 7 y Alemanes 25 en lo referido a la vajilla de barniz negro (infra)-, y el hecho de que se trata de un hito en la arqueología urbana de Sevilla, las que nos han llevado finalmente a incluir esta intervención en nuestro trabajo.

M. Vera pudo diferenciar hasta 8 niveles estratigráficos y cuatro fases constructivas, que se extienden sin solución de continuidad desde finales del siglo IV a.C. hasta el V d.C. (Vera 1987: 43 ss).

El Nivel I es un depósito indeterminado situado directamente sobre la tierra virgen. En él aparecen algunos ejemplares de ánforas Pellicer B-C junto con cerámicas comunes de tradición local (urnas, cuencos y lebrillos de cuello estrangulado) que permiten fecharlo en un momento avanzado del siglo IV a.C.

En el Nivel II se documenta la primera fase edilicia, formada por dos muros de aparejo irregular trabado con barro o argamasa muy pobre en cal. Los depósitos asociados a la construcción y amortización de esta estructura aportaron un amplio elenco de materiales, compuesto fundamentalmente por cerámicas comunes y ánforas Pellicer B-C, a los que habría que sumar algunos ejemplares de los tipos Pellicer D, Ramón T-12.1.1.1 y Ramón T-8.2.1.1, que nos sitúan en torno al siglo III a.C. Esta cronología vendría confirmada por la aparición en la parte superior de un tesorillo formado por cinco lingotes y cuatro monedas de plata cartaginesas, asociado a un estrato de incendio (Nivel III) con restos de vigas carbonizadas y utensilios quemados por el fuego. Fernández Chicarro fechó el tesorillo entre los años 210 y 205 a.C. (Fernández Chicarro 1952: 6370), lo que permitió a Collantes relacionar este nivel de

3. Consideramos que el Nivel IV, fechado por Vera entre la segunda mitad del siglo II y comienzos del I a.C., debe situarse o en este último momento o muy a fines del II a.C.

4. Insistimos en que, a pesar de la fiabilidad de la secuencia ofrecida por M. Vera, se trata de una propuesta realizada a partir de un material mal o escasamente contextualizado, en la que a veces se han agrupado los especímenes con criterios tipológicos y otras veces realizado selecciones de material (Vera 1987: 50, respecto a las lucernas) que no tienen por qué haber sido arbitrarias, pero que obligan a una cierta cautela en el manejo de estos datos. destrucción con la conquista de la ciudad por las tropas romanas al final de la II Guerra Púnica (Collantes de Terán 1977: 66).

El siguiente nivel (IV) no se ha asociado a estructura alguna, aunque ofreció abundantes cerámicas de tradición local (lebrillos, vasos caliciformes, urnas, etc.), algunas ánforas Pellicer D y las primeras importaciones de vajilla campaniense. Abarcaría la primera mitad del siglo II a.C.

El nivel V corresponde a un momento de fines del siglo II o principios del I a.C. en el que se afirma (Vera 1987: 50) que se construye un edificio con solería de ladrillos en tres o cuatro hiladas superpuestas que se drena o mantiene seco gracias a que se levantó sobre un encachado de piedras irregulares de 20 a $25 \mathrm{~cm}$. de potencia. Ante la ausencia de material gráfico, uno tiene la impresión de que se está describiendo en realidad un muro de ladrillos con cimentación de piedras irregulares, cuya edilicia desentona un tanto con la propuesta cronológica; o tal vez un encachado de piedras similar al del solar de la calle Abades (infra), amortizado con posterioridad por sucesivos pavimentos de ladrillos. En cualquier caso, los materiales que se analizan parecen homogéneos desde el punto de vista cronotipológico quedando, pues, por determinar su correcta relación con las estructuras descritas. Se documentan producciones comunes locales, ánforas Pellicer D y ánforas itálicas del tipo Dressel 1A, aunque predominan con mucho las campanienses, especialmente de la clase A, estando presentes las formas Lamb. 5, 5/7, 6, 8b, $27 b, 33 b$ y 36 . En Campaniense B se registra un bol de la forma 1 de Lamboglia, mientras que las lucernas corresponden a las formas 1B de Dressel y E de Ricci. En conjunto, se trata de un repertorio material de fines del siglo II o principios del I a.C., más cercano quizás al de Abades que al de Argote de Molina (infra), lo que no resulta desmentido por las tipologías de las ánforas Dressel 1A y Pellicer D, cuyos bordes corresponden a formas relativamente antiguas.

El Nivel VI parece situarse en un momento intermedio entre el "pavimento" de la fase anterior y la construcción de un complejo termal a comienzos de época imperial, por lo que en principio puede datarse a lo largo del siglo I a.C. No se relaciona con estructuras constructivas evidentes y está dominado nuevamente por las campanienses, que no son tan numerosas como en la fase anterior y que corresponden ahora a la clase B. El repertorio, más monótono, se compone de las formas Lamb. 3 y 5. Se incluyen ahora también (Vera 1987: fig. 9) algunas formas de cerámica común sin decorar, especialmente grandes cuencos y ollas de cuello 


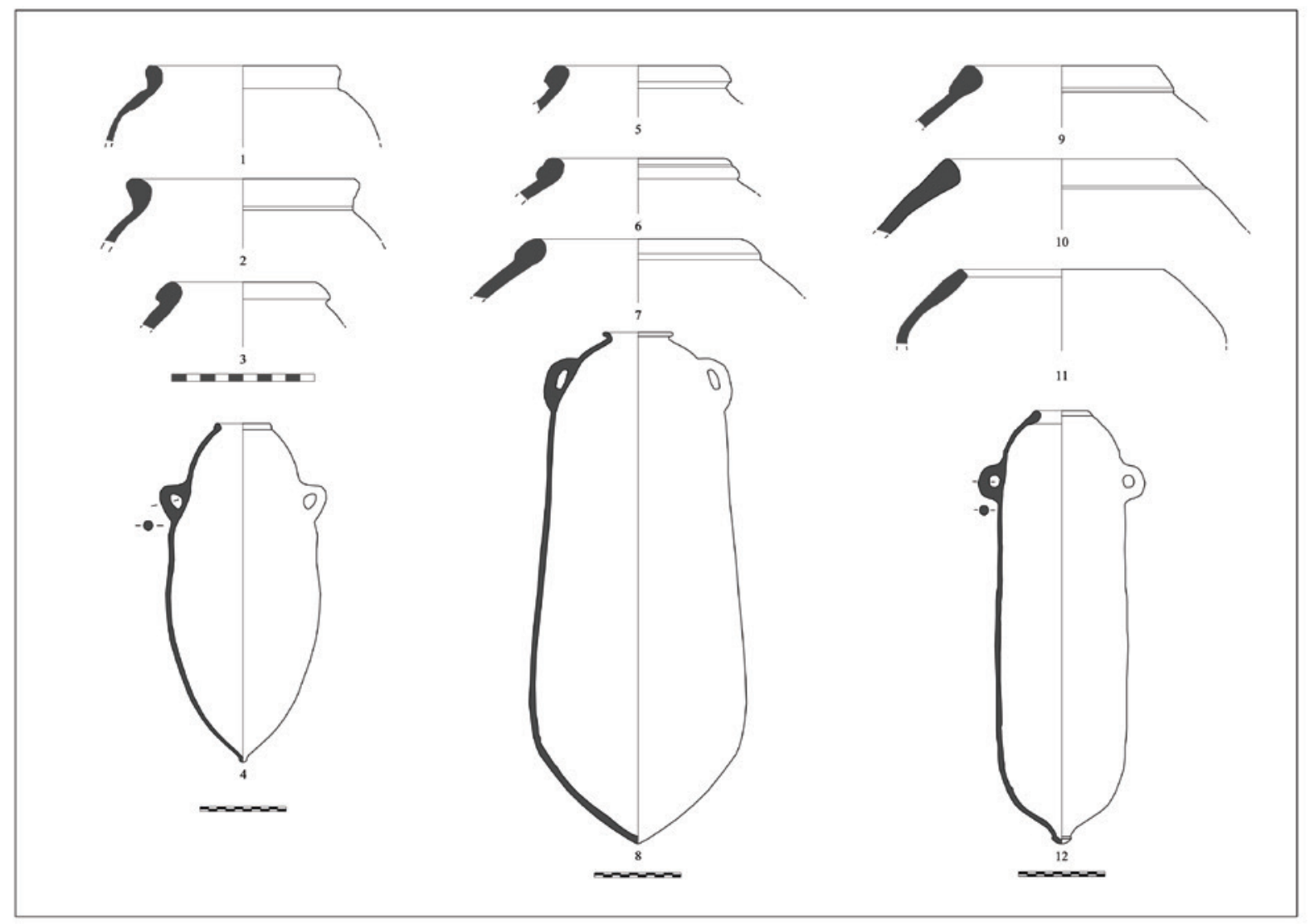

Figura 2. Ánforas de producción local. Pellicer C: 1-3, 4 (prototipo de Cerro Macareno); Pellicer B: 5-7, 8 (prototipo de Cerro Macareno); Pellicer D: 9-11, 12 (prototipo de Las Cumbres).

cilíndrico y borde engrosado al exterior, a veces con ligero bisel interno para recibir una tapadera. El conjunto creemos que puede fecharse en el tercio central del siglo I a.C., hallándose más cerca de los repertorios de la calle Alemanes que de los de Argote de Molina (infra). A partir del Nivel VII, los materiales corresponden ya a época imperial romana.

Argote de Molina, 7 (2081)

Durante la excavación de este solar se llevaron a cabo dos sondeos estratigráficos con objeto de registrar la totalidad de la secuencia antrópica hasta tierra virgen (Campos 1986). El primero de estos sondeos (corte 3) no pudo agotarse debido a problemas técnicos, alcanzando una profundidad de 6,60 m. (nivel 26). El segundo sondeo fue excavado en toda su extensión hasta los 7,30 m. (niveles 25 a 30), reduciéndose progresivamente hasta llegar a los 8,80 m. (niveles 31 a 34), donde supuestamente apareció el sustrato natural.
La ocupación más antigua se fechó a finales del siglo V a.C. (nivel 31). Sin embargo las primeras importaciones no aparecieron hasta los niveles 26 y $25 \mathrm{~A}$, correspondientes a la amortización de una estructura formada por un muro de piedra alcoriza y adobes, asociado a un pavimento de tierra apisonada. Se trata de dos bordes de ánforas de producción gaditana del tipo "Carmona" o T-8.2.1.1, un borde de ánfora grecoitálica, así como varios bordes de ánforas de tradición púnica, pertenecientes en este caso a la forma $\mathrm{D}$ de Pellicer. Algunas de estas últimas presentan un labio indiferenciado, marcado únicamente por un leve engrosamiento al interior (fig. 2: 11), lo que suele constituir un rasgo típico de las producciones de finales del siglo III, pero sobre todo del II a.C. (García y González 2007: 555). Coincide, por tanto, con la cronología del ánfora T-8.2.1.1, que puede llegar a finales del siglo II a.C. (Sáez y otros 2004: 123). Junto a estos contenedores aparece un mortero de tradición púnica (GDR 3.1.1) con el labio engrosado y un apéndice interior 
muy desarrollado, como corresponde a los ejemplares más evolucionados (Ruiz Mata 1987: 311), así como un borde de cerámica tosca y perfil triangular, con una leve acanaladura en la parte superior (fig. 3: 15), que podemos relacionar con las ollas de cocina documentadas en los niveles tardopúnicos de la necrópolis de Cádiz (Niveau de Villedary 2001-2002: 283). Por lo que respecta a la vajilla de mesa, tenemos un fragmento atípico de tipo Kouass y un fondo de cerámica megárica perteneciente probablemente a una pátera o un bol, cuya cronología debemos situar también a finales del siglo III o más bien a inicios del II a.C.

Las producciones locales están representadas por los tipos habituales de finales del siglo III a.C. (García y González 2007: 531-533), como son los vasos caliciformes, las urnas bitroncocónicas, los lebrillos de perfil evolucionado y las urnas globulares de cuello corto y estrangulado, a lo que habría que unir las ollas de cocina de borde engrosado (fig. 3: 14), en consonancia con los contextos exhumados en otras localidades del Bajo Guadalquivir, como los niveles 6 y 5 de Cerro Macareno (Pellicer y otros 1983: figs. 25-27) o el estrato XXVIII de Vico, en Marchena (Bandera y Ferrer 2002: fig. 17).

Los niveles 25 al 23 constituyen un relleno arcilloso uniforme sobre el que se asienta la siguiente estructura, ya en el nivel 22: dos muros de mampostería careada unida con argamasa. El primero se desarrolla longitudinalmente en dirección norte-sur, mientras que el segundo forma una esquina en ángulo recto, cuyos extremos se introducen en los testigos sur y oeste. En su interior encontramos de nuevo abundantes fragmentos de ánforas de procedencia gaditana: un borde residual del tipo 8.1.1.2, otros dos del tipo 8.2.1.1 y dos ejemplares del ánfora T.9.1.1.1, cuya fabricación se inicia a finales del siglo III o inicios del II, aunque puede prolongarse hasta bien entrado el siglo I a.C. (Carretero 2004: 433-434). Son también frecuentes las producciones locales correspondientes a las formas B-C y D de Pellicer, destacando sobre todo las variantes de borde indiferenciado, así como los labios de sección oval y ligeramente engrosados. En estos niveles hacen ya acto de presencia las importaciones centromediterráneas, representadas por un ánfora del tipo Mañá D (T-5.2.3.1) y otra del tipo Mañá C2 (T-7.2.1.1). Su difusión en la Península Ibérica se sitúa entre finales del siglo III y mediados del II a.C. (Ramón 1995: 198 y 205). Una cronología similar podemos atribuir a un mortero de tradición norteafricana (fig. 12: 2), correspondiente a la serie 131 de Lancel (1987: 103-104). Encontramos también un mortero de producción gaditana (GDR
3.1.1), similar al hallado en los niveles anteriores (fig. 3: 4), así como un plato de pescado realizado en cerámica de Kouass (fig. 4: 33) perteneciente a la forma II de Niveau (2003: 46-48). Por lo que respecta a las primeras importaciones itálicas, éstas están representadas por un fragmento de ánfora grecoitálica antigua (tipo A de Will) y un asa de Dressel 1A, que nos sitúa ya a mediados del siglo II a.C.

La cerámica común de fabricación local apenas acusa cambios con respecto a los repertorios registrados en los contextos anteriores: cuencos de casquete esférico, urnas globulares de cuello corto, urnas con baquetón, cuencos-lucerna, lebrillos, etc. No obstante, sí se aprecia una reducción paulatina de la decoración pintada hasta prácticamente desaparecer en el paso al siglo I a.C. Por último, hace su aparición en este momento un tipo de urna globular con el cuello cilíndrico, poco desarrollado, que se convertirá en un ítem característico de las producciones comunes del valle del Guadalquivir durante el periodo republicano (fig. 7: 9). Se caracteriza por presentar un borde engrosado al exterior de sección triangular o trapezoidal, en ocasiones ligeramente caído, y una decoración sencilla que se limita a una sola banda de color vinoso situada en la cara superior del borde o en el cuello.

Los niveles 20 a 18 de Argote de Molina corresponden a la construcción, ya en época republicana, de un edificio de sillares asociado a un pavimento de signinum (niveles 18 y 19) y cimentado sobre un encachado de piedras y fragmentos cerámicos (nivel 20). El conjunto de materiales recuperados de estas estructuras constituye una muestra significativa de la composición de los repertorios cerámicos en la ciudad de Hispalis ya en los decenios iniciales del siglo I a.C.

Aunque la publicación de la intervención (Campos 1986: 19) proponía fechar estos niveles en la segunda mitad del siglo II a.C., tanto la tipología de los materiales en ellos contenidos como los porcentajes constatados de cada variante de cerámica de barniz negro nos inclinan por una fecha algo más reciente para la datación del conjunto, en torno, como se ha indicado, a los decenios iniciales del siglo I a.C. El repertorio formal de las clases A (Lamb. 5; 5-7; 6; 27 a, b y c; 33 b; 34 b y 36) y B (Lamb. 1, 3, 5, 6, 7, 8, 8b, 10 y Pedroni $700)$ es realmente variado y responde, como se ha dicho, al estado de la tipología a principios del siglo I a.C. En cuanto a los porcentajes, se documenta en estos niveles un $42,55 \%$ de Campaniense A frente al 57,45\% de Campaniense B, de los cuales un 33,36\% son etruscas o "verdaderas", un 50\% del "círculo de las B" y un $13,63 \%$ no identificadas. Esto es exactamente lo 


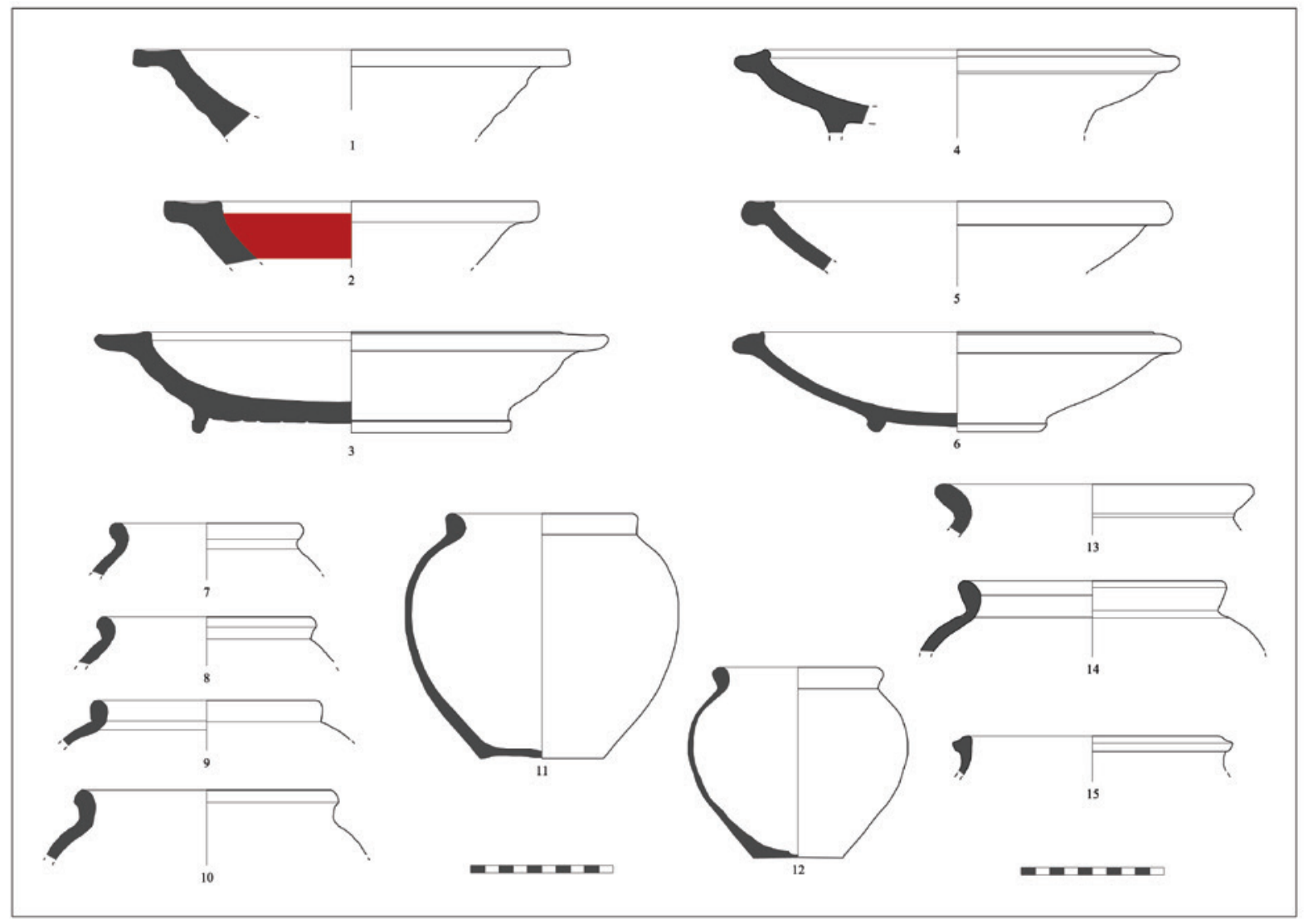

Figura 3. Cerámica de cocina de producción local. Morteros: 1, 2, 4 y 5, 3 y 6 (prototipos de Itálica); ollas de tradición turdetana: 7-10, 13 y 14, 11 y 12 (prototipos de Cerro Macareno); ollas de tradición púnica (GDR 12.3.1): 15.

contrario de lo que sucede en las UU.EE. 371 y 372 de Abades, lo cual, a nuestro entender, indica en este caso una prioridad cronológica de dicha excavación con respecto a la de Argote de Molina.

Las ánforas, entre las que se incluyen fragmentos ¿residuales? de las formas T.8.1.1.2 y T.8.2.1.1, presentan bordes evolucionados del tipo Pellicer D, así como bordes del tipo gaditano 7.4.3.3, lo que parece también más propio de inicios del siglo I a.C. que de fines del anterior. Aunque la producción de ánforas del grupo Ramón 7.4.3 arranca de los decenios finales del siglo II a.C. (Ramón 1995: 210-213; Sáez 2008: 647), lo cierto es que su generalización en los contextos mediterráneos no se produce hasta los años iniciales del siglo I a.C. Las ánforas itálicas presentan un repertorio igualmente más variado que en Abades y en apariencia también fechable a inicios del siglo I a.C.: Dressel 1A, 1B, 1C y Lamboglia 2 adriática.

Entre las formas mejor representadas en cerámica común de procedencia itálica (un conjunto realmente excepcional sin parangón en la ciudad de Sevilla) se encuentran los platos de borde sencillo (Emporiae 158.15, Burriac 549) o bífido (Vegas 14, Torre Tavernera 4.10), las fuentes de barniz rojo pompeyano (Luni 1), las cazuelas (Celsa 79.28), las sartenes (Celsa 84.13596), las tapaderas (Celsa 80.13596). No faltan aquí las ollas (Vegas 2), aunque su aporte numérico es muy reducido con respecto al de las formas abiertas (en general, véase fig. 12). Esto contrasta claramente con la composición formal del repertorio tradicional turdetano de los mismos niveles, en los que son frecuentes las ollas de pasta gris y borde vuelto para cocinar $(25 \%)$; los morteros $(4,42 \%)$, que ahora comienzan a hacerse en formas derivadas de los itálicos Emporiae 36.2; los lebrillos $(10 \%)$, a veces con bordes redondeados que, como se verá, no existen en las producciones prerromanas, y las urnas pintadas de borde triangular. Los platos y las cazuelas son aún muy escasos, destacando las de borde bífido (1,92\%), a imitación de las cazuelas itálicas del tipo Vegas 14. Finalmente, comienzan a aparecer con 
cierta frecuencia $(4,23 \%)$ las jarras, de una o dos asas (fig. 7: 6).

Las lucernas, por su parte, están igualmente bien representadas, predominando los tipos tardorrepublicanos de producción itálica: Ricci G, Ricci H y Dressel 2.

\section{San Isidoro, 21-23 (147)}

En el sondeo realizado en la calle San Isidoro se obtuvo una potente secuencia de $8,85 \mathrm{~m}$. de profundidad, dividida en 26 niveles arbitrarios que se extendían desde finales del siglo VIII a.C. hasta la II Guerra Púnica o inicios del siglo II a.C. (Campos y otros 1988). No obstante, los niveles 1 al 10, correspondientes a las fases históricas más recientes, fueron desechados debido a la intensa alteración provocada por la cimentación del último episodio constructivo y a la presencia de varios pozos negros en distintos puntos del corte.

El primer nivel que vamos a analizar es el 17, constituido por un pavimento de arcilla apisonada y los rellenos que lo amortizan. En su interior encontramos dos bordes muy fragmentados de ánforas púnicas correspondientes al tipo 8.2.1.1, así como otros dos bordes asimilables a la forma D de Pellicer, que nos sitúan en el siglo III a.C. Un asa de sección oval, perteneciente probablemente a un ánfora de tradición griega y no púnica, ha sido interpretada como una intrusión, ya que ni siquiera aparece en el inventario de materiales publicado por sus excavadores (García y González 2007: 534). Junto a estas ánforas se hallaron varios cuencos comunes de casquete esférico, cocidos en atmósfera oxidante y sin apenas decoración, un cuenco lucerna, dos bordes de plato turdetano de labio vuelto, con el característico barniz rojizo al interior, además de un lebrillo y varios bordes de urna de mediano tamaño (ibidem). En su conjunto, este contexto presenta claras analogías con los niveles 9 al 7 del Cerro Macareno (Pellicer y otros 1983: figs. 29-34), así como con los contextos exhumados en los últimos niveles prerromanos de Vico (Bandera y Ferrer 2002: figs. 16-18).

Los niveles 16 al 14 conforman depósitos de relleno relacionados con la anulación de la estructura anterior y el inicio de una nueva ocupación (nivel 12). Aquí se registró un ejemplar casi completo del ánfora T-8.2.1.1 (fig. 8: 5), así como el borde de una variante temprana del tipo Mañá/Pascual A4 (T-11.2.1.3 o T-11.2.1.4). Esta última puede considerarse residual, ya que su producción termina a finales del siglo $\mathrm{V}$ o principios del IV a.C. (Ramón 1995: 235-236). Encontramos también el borde de un mortero de producción gaditana, correspondiente al tipo GDR 3.1.1, además del repertorio habitual en cerámica común a torno: cuencos, platos, vasitos de perfil en $\mathrm{S}$, lebrillos de cuello estrangulado $\mathrm{y}$ urnas de distinto formato.

La siguiente fase de ocupación está formada por los restos de un muro de mampostería caliza y alzado de adobe (nivel 12), que queda a su vez anulado por un nivel de incendio que cubre toda la superficie del corte (nivel 11). La cronología de esta destrucción viene dada por los restos de un ánfora Pellicer D de borde indiferenciado y un asa de sección oval perteneciente probablemente a un contenedor itálico del tipo Dressel 1, que nos lleva ya a mediados del II a.C. Sobre este nivel de incendio se superpone un depósito de relleno (nivel 10) donde encontramos de nuevo varias ánforas Pellicer D y un ejemplar del tipo 8.2.1.1, junto a lo que podría ser un mortero GDR 3.1.1 de perfil muy evolucionado o un gran plato. Por su parte, la cerámica común (cuencos y platos en su mayoría) mantiene los mismos tipos con escasa variación, así como la tendencia a la reducción del aparato decorativo.

Mármoles, 9 (35)

Al igual que en los casos anteriores, la secuencia estratigráfica obtenida en la calle Mármoles (con una potencia total de 5'04 m.) se realizó siguiendo niveles arbitrarios, lo que limita en gran medida la identificación y análisis de las fases de ocupación (Escudero y Vera 1990: 407-410). Desgraciadamente, los contextos prerromanos documentados en esta intervención se encontraban bastante alterados, debido sobre todo a las frecuentes intrusiones procedentes de varias fosas de expolio realizadas a principios de la Edad Media, así como por el rebaje practicado para la construcción de un edificio monumental en época imperial romana.

Se trata de dos depósitos superpuestos, asociados a un muro de calcarenita, y los restos de un fuego (estratos 7 y 6). En nuestra opinión, debe tratarse de un único relleno de colmatación que amortizaría dicha estructura, tanto por la homogeneidad de los materiales como por la aparición en alguna ocasión de fragmentos de un mismo recipiente en ambos estratos (García y González 2007: 537). Estos niveles proporcionaron dos bordes de ánfora, uno del tipo 8.1.1.2 y otro asimilable a la forma D de Pellicer, así como el asa de un ánfora grecoitálica. Documentamos también un fragmento amorfo de cerámica de Kouass, lo que en conjunto permite fechar esta fase sin gran precisión en el siglo III a.C. Las producciones locales están compuestas por cuencos de casquete esférico de diferentes tamaños y variantes, cuencos-lucerna, urnas globulares y bitroncocónicas de 


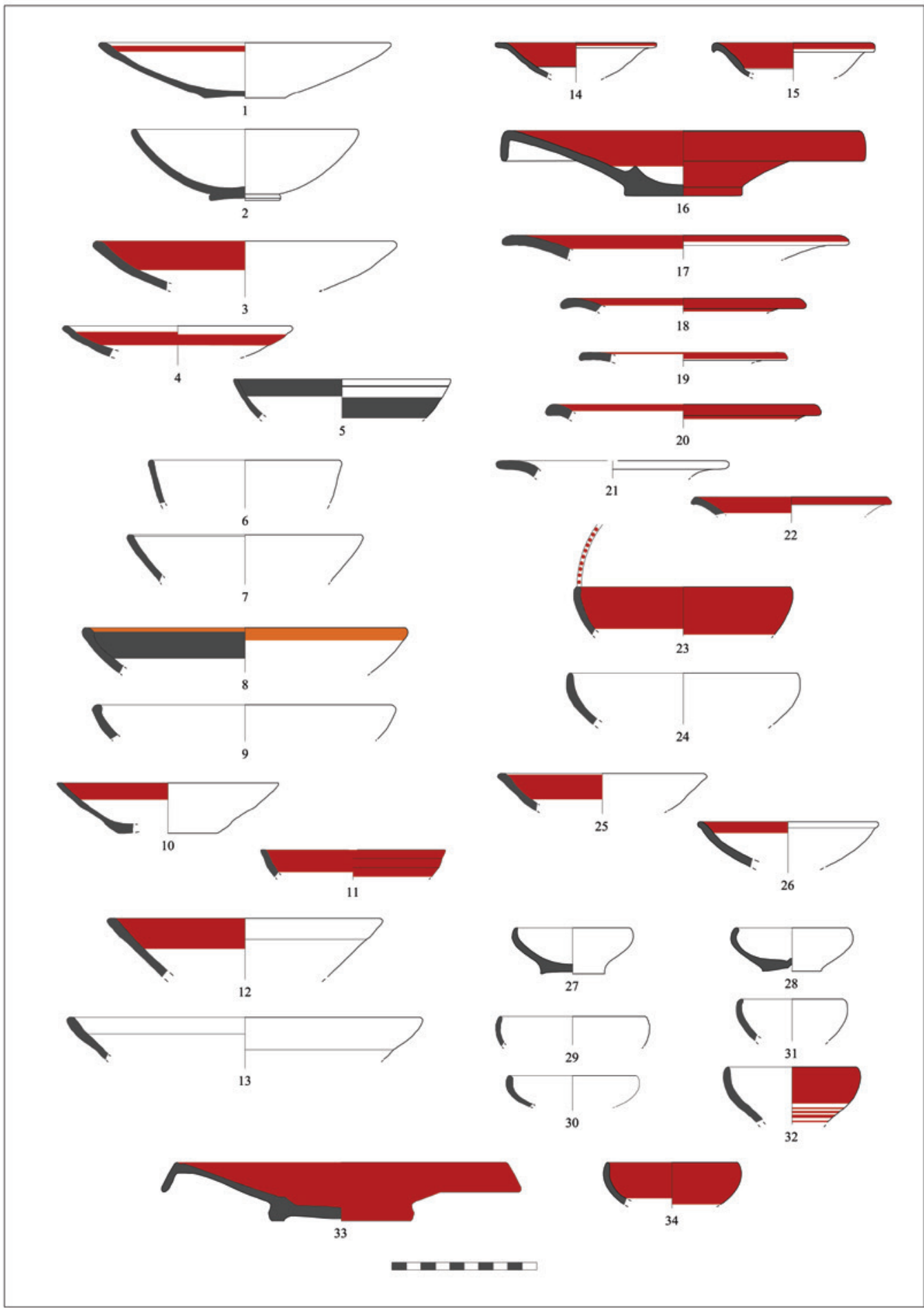

Figura 4. Cerámica común de producción local. Cuencos: 1 y 2 (prototipos de Itálica y Alhonoz), 3-6 (tipo Escacena I-A), 7-9 (Escacena I-B), 10 y 11 (Escacena I-C), 12 y 13 (Escacena I-D), 23 y 24 (Escacena I-H), 25 y 26 (Escacena I-I); platos: 14 y 15 (prototipos de Montemolín), 16 (prototipo de Alhonoz), 17-19 y 21 (tipo Escacena II-A), 20 y 22 (Escacena II-B); cuencos-lucerna: 27 y 28 (prototipos de Alhonoz e Itálica), 29-32. Vajilla gaditana tipo "Kuass". Plato: 33 (forma Niveau II); copa: 34 (Niveau IX). 
cuello corto y estrangulado, a lo que habría que unir un lebrillo decorado al interior del borde con trazos verticales paralelos y un fragmento de plato de pescado correspondiente a la forma II-A de Escacena. En conjunto, nos encontramos ante un repertorio formalmente monótono, con una decoración sencilla de líneas y bandas rojas o, más frecuentemente, sin decoración alguna. Las pastas suelen estar ya muy depuradas, con un predominio de la cocción oxidante que se impondrá definitivamente durante las siguientes centurias.

El siguiente nivel (estrato 5), relacionado con la preparación del terreno para la construcción del mencionado edificio, ofreció un segundo borde de ánfora T-8.1.1.2, aunque en este caso asociado a varios ejemplares de vajilla campaniense, ánforas romanas de cronología tardorrepublicana y altoimperial, cerámica común local y recipientes de cocina de tradición itálica.

\section{Fabiola, 8 (127)}

En la calle Fabiola 8, los niveles (arbitrarios) excavados corresponden en su totalidad a época romana. $\mathrm{La}$ estratigrafía se inicia según los excavadores en momentos republicanos, época a la que pertenecerían los niveles 16 al 18 del corte 4 (Escudero y otros 1987: 593, fig. 2). Como se verá, esta fecha debe ser ligeramente ampliada en su margen inferior para incluir los primeros años del principado de Augusto. La relación de estos niveles con la única estructura contemporánea documentada en el sondeo, un muro de sillarejo irregular, no es del todo clara, pero en cualquier caso parece evidente por los datos de la publicación que estos depósitos - con una potencia total de $0,50 \mathrm{~m}$.- corresponden al uso y amortización de dicho muro en torno al último tercio del siglo I a.C. Esta datación descansa en los materiales cerámicos asociados a los citados niveles que hemos podido estudiar en el Museo Arqueológico de Sevilla. Se componen mayoritariamente de fragmentos ánforicos de las formas T-7.4.3.3, Dressel 1A, Dressel 2-4, ¿Haltern 70?, Haltern 70 small variant u Ovoide 4 de Rui de Almeida (Almeida 2008), Oberaden 71/ Dressel 20 y Dressel 7-11 (García Vargas 2009: fig. 5). El resto del elenco cerámico está formado por campanienses del círculo de las B (formas Lamb. 1 y 5), por un fondo y un borde de TSI de la forma Conspectus 1 , por cerámicas itálicas de la variante denominada "rojopompeyano" (forma Luni 2-4) y por cerámicas comunes de tradición turdetana, entre las que destacan las urnas con borde simple redondeado o de tendencia rectangular. Este rasgo resulta característico de las producciones tardías (siglo I a.C.), pues se documenta también en los depósitos de época temprano-augustea exhumados en la calle Santa Verania de Alcalá del Río (Cervera y otros 2007). En Fabiola 8 comparece además un fragmento de lucerna de volutas del tipo Dressel 9B que debe fecharse a partir de época augustea. Por lo que respecta a las importaciones del ámbito púnico, únicamente el nivel 16 proporcionó un borde de ánfora de fabricación gaditana, correspondiente al tipo Mañá $\mathrm{C} 2 \mathrm{~b}$ o T-7.4.3.3 de Ramón. Su cronología no desentona con la del resto del material, que nos sitúa en el último cuarto del siglo I a.C.

Sobre el nivel 16, el nivel 14 estaba compuesto mayoritariamente por ánforas de los tipos Oberaden 71/ Dressel 20 y Haltern 70 small variant de tipología antigua, así como por fragmentos atípicos de Campaniense del "círculo de las B". Todas serían residuales ciertamente si se repara en el hecho de que los excavadores incluyen fragmentos de TSH entre los hallazgos de este nivel, aunque nosotros dudamos seriamente de dicha atribución, pues se trata de un material cerámico que no es coherente estratigráficamente con el resto de la vajilla documentada. De hecho, no hemos podido localizar estas sigillatas hispánicas entre los materiales de la excavación conservados en el Museo Arqueológico Provincial de Sevilla.

Abades, 41-43 (2026)

En esta excavación se llevaron a cabo dos sondeos estratigráficos, uno junto a la calle Abades (Corte 18A), con objeto de analizar el origen y evolución de esta vía, y otro en el extremo opuesto de la parcela, en un pequeño patio (Corte 15A), donde presumiblemente se podía obtener una secuencia más completa de la ocupación del solar (Jiménez 2002). En este último, de $4 \mathrm{~m}^{2}$ de extensión, se registraron hasta ocho fases constructivas que se suceden sin apenas interrupción desde finales del siglo IV a.C. hasta el siglo IV d.C. (Jiménez y otros 2006). No obstante, debido a las dificultades técnicas y a la falta de espacio para proseguir la excavación, el sondeo se detuvo a una profundidad de $6,85 \mathrm{~m}$. bajo el rasante sin agotar la estratigrafía.

La Estructura 1 descansa sobre un depósito de nivelación (UE 432) en el que apareció un borde de ánfora Maña-Pascual A4, correspondiente a la variante T-12.1.1.1 de Ramón (fig. 8, 2). Su producción se extiende entre la segunda mitad del siglo IV a.C. y el siglo III a.C. (Ramón 1995: 238), aunque su posición estratigráfica en la secuencia permite fechar este nivel de ocupación a finales del siglo IV a.C. Está formada por un murete de mampostería caliza y alzado de adobe 


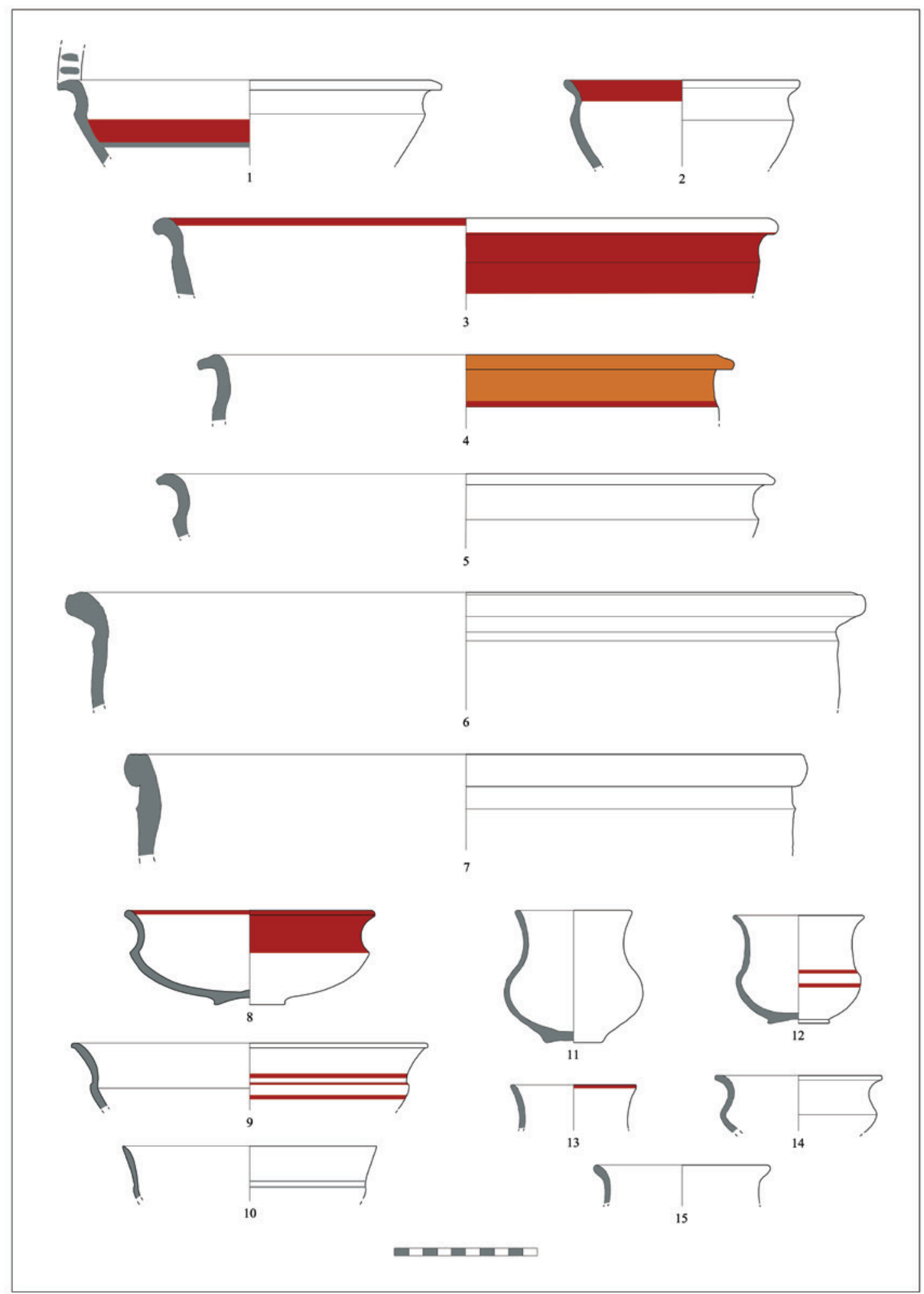

Figura 5. Cerámica común de producción local. Lebrillos: 1-6; escudillas: 7 (prototipo de Itálica), 8 y 9; vasos caliciformes: 10 y 11 (prototipos de Itálica), 12-14. 
asociado a un pavimento de arcilla y cal (UE 431). En su interior aparecieron los restos de varios cuencos de casquete esférico, un fragmento de urna con baquetón y el borde de una urna globular de cuello corto y estrangulado decorada con filetes de color rojizo. Esta estructura fue amortizada por dos rellenos de nivelación superpuestos compuestos por desechos domésticos y escorias de actividades industriales (UU.EE. 429 y 428). La cerámica asociada a esta matriz es muy abundante aunque monótona desde el punto de vista formal: de nuevo cuencos de casquete esférico, cuencos-lucerna, urnas globulares de cuello corto y urnas bitroncocónicas con decoración pintada, lebrillos de cuello estrangulado y un vaso de perfil quebrado sin decoración, junto a un asa de ánfora y restos residuales de cerámica a mano. Se trata de un contexto bastante coherente desde el punto de vista cronológico, cuyas analogías con los niveles 9 y 10 de Cerro Macareno (Pellicer y otros 1983: figs. 32-35) permiten situarlo con facilidad entre finales del siglo IV e inicios del III a.C.

Sobre estos depósitos se construyó la siguiente estructura, consistente de nuevo en un muro de aparejo irregular y alzado de adobe asociado a un pavimento de arcilla roja con enlucido de cal (UE 426). Entre este pavimento y el depósito UE 428 se situó un relleno arcilloso de entre 8 y $10 \mathrm{~cm}$. se espesor destinado a dar asiento a la nueva ocupación. En él aparecieron también restos de producciones locales de carácter doméstico: lebrillos y cuencos fundamentalmente, así como algunos fragmentos atípicos de ánforas púnicas y cerámica a hecha a mano. Sobresale un vaso caliciforme de perfil quebrado (fig. 5: 14), poco habitual en los contextos prerromanos de Sevilla, y el borde de una olla de cocina de factura tosca (fig. 3: 10), muy similar a las documentadas en otras localidades del Bajo Guadalquivir, como en el estrato XX de Vico (Bandera y Ferrer 2002: fig. 13), de mediados del siglo IV, o en el nivel 5 de Cerro Macareno (Pellicer y otros 1983: fig. 24), fechado a finales del siglo III a.C.

La Estructura 2 fue amortizada a su vez por dos niveles de relleno (UE 422/423 y UE 420) destinados a dar asiento a la siguiente fase edilicia. En ellos se hallaron algunos restos anfóricos de producción gaditana, en este caso se trata de un borde de ánfora tipo "Tiñosa" o T-8.1.1.2 y otro borde correspondiente al ánfora tipo "Carmona" o T-8.2.1.1. Ambas conviven a lo largo del siglo III a.C. aunque podrían fecharse en su primera mitad, ya que aparecen asociadas a dos morteros de tradición púnica pertenecientes a la variante más antigua (fig. 3: 1-2), de borde plano y sección cuadrangular, con una suave acanaladura en su parte superior
(Ruiz Mata 1987: 311). Junto a ellas comparece un repertorio amplio de cerámicas comunes, representadas principalmente por los cuencos, con múltiples variantes tanto en lo que respecta al tamaño como a la forma que adopta el borde, y los lebrillos de cuello estrangulado. En ambos casos se continúa apreciando una tendencia a la simplificación de la decoración, así como una sensible mejora en las pastas, con cocciones oxidantes y engobes claros y homogéneos, como viene siendo habitual en las producciones de los siglos III y II a.C. Completan este elenco varios fragmentos de urna con baquetón, decoradas con bandas y líneas rojas y/o negras, un borde de urna de cuello acampanado, un vaso de cuello estrangulado y tendencia ovoide, así como dos ejemplares de cuencos-lucerna. Por lo que respecta a la cerámica de cocina, se registran dos ollas de borde engrosado, del mismo tipo que el espécimen identificado en la ocupación anterior.

La Estructura 3, consistente en un muro muy deteriorado de guijarros y mampostería caliza (UE 418), se asienta sobre un estrato de nivelación de $23 \mathrm{~cm}$. de espesor aproximadamente (UE 419). En su interior aparece de nuevo un mortero de tradición púnica, en este caso de perfil evolucionado (fig. 3: 5), asimilable al tipo GDR 3.1.1 de Cádiz, ya del siglo III a.C. (Sáez 2005: 152), así como un lebrillo de grandes dimensiones provisto de asas y un cuenco de casquete esférico. Esta estructura está colmatada asimismo por un nivel de relleno (UE 417) donde encontramos un fragmento atípico de cerámica de Kouass, con idéntica cronología, y un ánfora de producción local de la forma $\mathrm{B} / \mathrm{C}$ de Pellicer. Aquí se entremezclan restos de otras épocas (cerámicas a mano, cerámicas grises, etc.) con formas cuya producción se generaliza a partir de mediados del siglo IV a.C. Es el caso de los vasos para beber, las ollas de cocina de factura tosca y las urnas globulares con asas acanaladas a la altura de la panza, correspondientes a la forma IX-A de Escacena. Estas últimas se encuentran ya presentes en Cerro Macareno desde el nivel 10, de finales del siglo IV a.C. (Pellicer y otros 1983: fig. 35), aunque en esta región son habituales sobre todo en la siguiente centuria (Escacena 1987: 403). Las formas más comunes, sin embargo, siguen siendo los cuencos de casquete esférico, las urnas de cuello acampanado y los lebrillos. Entre los primeros se inicia en este momento la producción de la variante de borde biselado, lo que constituye un rasgo característico de los contextos del siglo III, como ha podido observarse en los últimos niveles prerromanos de Montemolín (García Vargas y otros 1989: 224) y Vico (Bandera y Ferrer 2002: fig. 13). Por lo que respecta a los lebrillos, comienzan ya a aparecer 


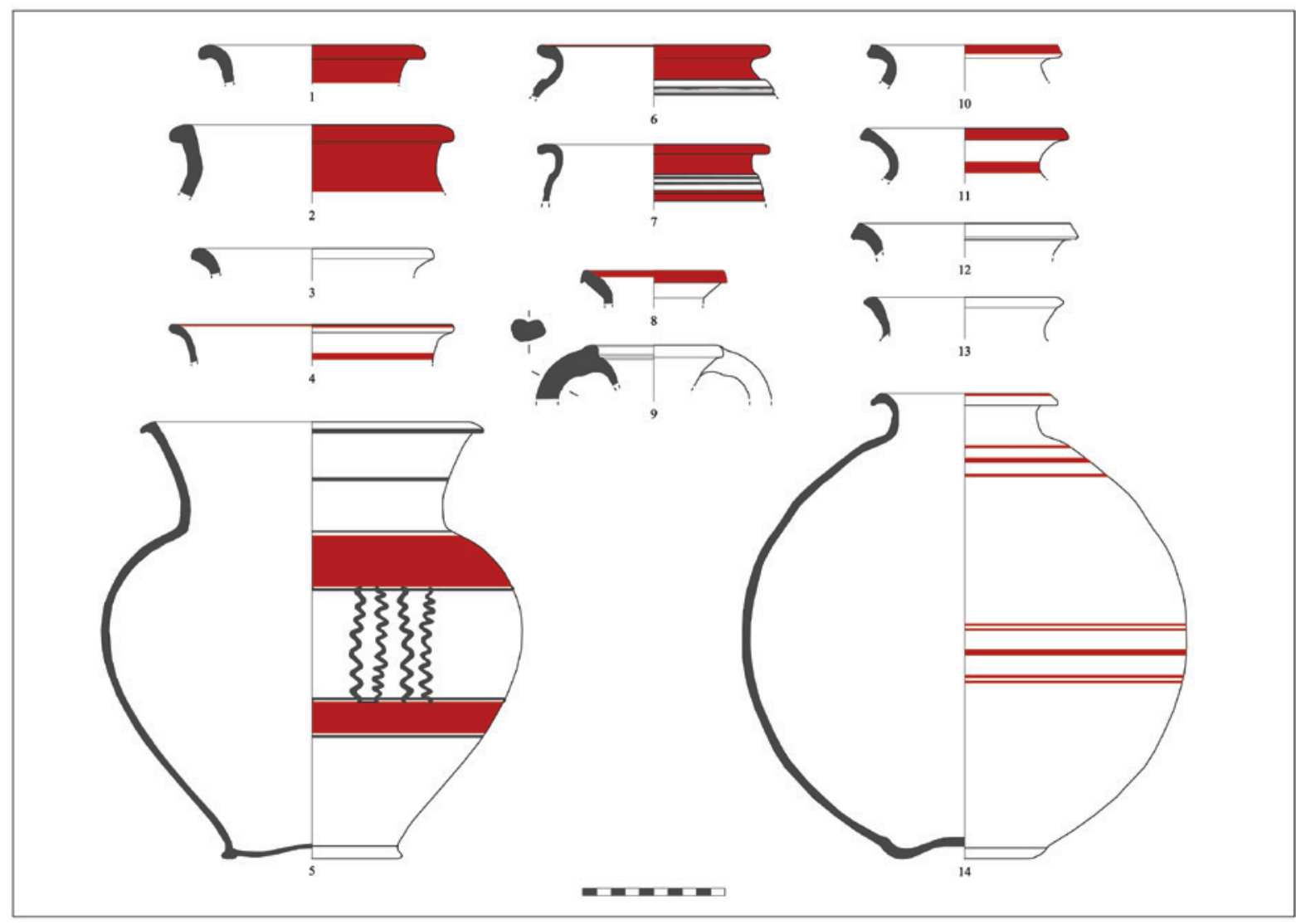

Figura 6. Cerámica común de producción local. Urnas de cuello acampanado 1-4, 5 (prototipo de Itálica); urnas con baquetón: 6, 7 (Alcalá del Río); urnas tipo "Cruz del Negro": 8 y 9; urnas globulares: 10-13, 14 (prototipo de Itálica).

ejemplares de gran tamaño con el borde engrosado de sección oval o almendrada (fig. 5: 6), un rasgo frecuente en las producciones locales a partir de finales del siglo III a.C. (Pellicer y otros 1983: 93).

La preparación para la construcción de la Estructura 4 está formada por otros dos depósitos sucesivos (UE 412/415 y UE 411). Aquí hallamos nuevamente un borde de ánfora púnica perteneciente al tipo 8.1.1.2 de Ramón y un asa que podemos adscribir a la misma forma, así como al tipo 8.2.1.1, además de las formas habituales en cerámica común: cuencos, urnas, lebrillos y ollas de cocina. La Estructura 4 consiste en dos muros de mampostería caliza trabados en ángulo recto (UU.EE. 381 y 405), el primero de los cuales servía asimismo de separación entre dos espacios interiores pavimentados con suelos de arcilla roja (UU.EE. 382 y 410). El material asociado a estos pavimentos está compuesto básicamente por fragmentos atípicos de cerámica común, un borde de lebrillo de perfil evolucionado y un plato de borde vuelto, decorado con una capa de engobe rojo al interior. Asimismo, encontramos un fragmento de cerámica campaniense correspondiente a la forma M.2154, que permite fechar su ocupación a finales del siglo III o inicios del II a.C.

La amortización de esta estructura se realizó mediante una serie de vertidos (UU.EE. 380, 409 y 372), sobre los cuales se levantó la primera ocupación de época romano-republicana (Estructura 5). Ofrecen un repertorio material abundante y diversificado, donde destacan ya las importaciones itálicas de la UE 372. Se trata, sobre todo, de cerámicas asignables al tipo A de las producciones campanas (Lamb. 6, Lamb. 28 a-b, Lamb. 31b, Lamb. 33b, Lamb. 36 y M. 3131), un repertorio característico de la fase media de producción, dentro de las cuales el vaso carenado del tipo Lamb. 28 a-b y el gobelete M. 3131 constituyen los elementos más antiguos, pues su fabricación concluye hacia mediados del siglo II a.C. La presencia de una u otra de estas formas en contextos peninsulares datados entre 150 y 130 a.C. parece abogar por una perduración de 
su circulación en Hispania hasta principios del último tercio de esta centuria (Marín Jordá y Ribera 2000; Principal 2000). Para el resto de las formas citadas, se constata la continuidad de su producción en A media hasta fines del siglo II, con las mismas características tipológicas. Todas ellas pasan a formar parte, también sin grandes variaciones formales, del repertorio de la variante tardía de la Campaniense A (100-50/40 a.C.). A ello ha de sumarse un fondo de cubilete de paredes finas de la forma Mayet I-Ricci 1/1, también de la UE 372 , cuya cronología es coherente con la que ofrecen las vajillas campanas.

Junto a estas importaciones aparecieron también dos bordes de ánforas de tradición púnica pertenecientes a la forma D de Pellicer. Uno de ellos presenta un perfil indiferenciado y de tendencia horizontal (fig. 2: 10), como viene siendo habitual en las producciones fechadas a partir de mediados del siglo II a.C. (García y González 2007: 555). El resto del material documentado en estas unidades corresponde al repertorio común de tradición local. Se trata fundamentalmente de urnas y cuencos de las variantes más comunes, a los que habría que añadir dos pequeños vasos para beber de perfil en $\mathrm{S}$, un fragmento de urna con baquetón, un plato común de pequeño formato y un cuenco de bordes entrantes asimilable a la forma I-H de Escacena, recubierto de engobe rojo al interior y al exterior, y con una decoración poco usual a base de puntos del mismo color dispuestos a lo largo del borde, que queda en reserva (fig. 4: 23).

La Estructura 5 mantiene la misma orientación y la misma técnica constructiva que las fases edilicias anteriores. Se documentaron dos muros trabados en ángulo recto (UU.EE. 373 y 404), realizados sobre un zócalo de mampostería caliza con alzado de tapial. Por su parte, el espacio delimitado por los muros fue pavimentado en dos fases sucesivas con suelos de distintas características. El más antiguo (UE 406), consistente en una torta de cal enlucida de rojo, sólo se ha conservado intacto en un pequeño sector. Este suelo fue sustituido posteriormente por otro de mayor entidad constructiva: un encachado de fragmentos cerámicos y losas irregulares de piedra caliza que podría interpretarse como la solería de un patio o una estancia abierta (UE 371). Los contextos relacionados con la construcción de esta estructura son menos fecundos en lo que a importaciones se refiere. No obstante, la elaboración del segundo pavimento con restos cerámicos permitió fechar la reforma de esta vivienda a finales del siglo II a.C. Destacan de nuevo las campanienses, que corresponden en su casi totalidad a la fase media de producción de la variante A: formas Lamb. 8b, Lamb. 27 a-b,
Lamb. 33b y Lamb. 36. Las tres últimas son comunes a la Campaniense A media y a la tardía, mientras que la forma $8 \mathrm{~b}$ resulta más frecuente en los conjuntos tardíos, aunque tiene su origen en los últimos momentos de la producción de la variante media (último cuarto del siglo II a.C.). Este es probablemente el momento en que deban fecharse estas cerámicas, si atendemos a la escasa presencia de vasos en Campaniense B de Cales, cuya recepción mayoritaria en el sur de Hispania se documenta a partir de principios del siglo I a.C. Estos últimos están representados por un fondo asignable a la forma Lamb. 1, que aparece en el repertorio de las campanienses calenas a partir de la fase media de la producción (130/120-90/80 a.C.), y por un bol asimilable a la forma 2614 de Morel. El color amarillento su pasta y la mala calidad de su barniz hace dudar de su pertenencia al taller de Cales, por lo que se trata probablemente de un ejemplar del círculo de las $\mathrm{B}$ más que de una $\mathrm{B}$ calena propiamente dicha. En la Campaniense de Cales, la forma M.2614 es en realidad más común en el repertorio de la variante antigua (200/130-120 a.C.) que en el de la media, aunque estos boles están presentes aún en Valencia en contextos del último cuarto del siglo II a.C. (Escrivá y otros 1992: 457). Una procedencia no campana, sino etrusca, puede señalarse para un borde de Campaniense B de la forma 5 de Lamboglia. Se trata de una pieza de indudable calidad técnica lo que, unido a su fina pasta beige sin desgrasantes visibles y a su barniz satinado y denso de color negro azulado, nos inclina a clasificarlo como un producto norditálico. La cronología inicial de las páteras de la forma 5 de Lamboglia en Campaniense B etrusca o "verdadera" se remonta al último cuarto del siglo II a.C. (Principal 2005: 54).

Las ánforas asociadas a este repertorio de vajilla de mesa son mayoritariamente contenedores de procedencia campana y forma Dressel 1A. El resto de las importaciones, un ánfora gadirita de la forma 9.1.1.1, un fondo de vaso itálico de paredes finas y un fragmento del cuerpo de un bol "megárico" de producción norditálica, no desdice una propuesta cronológica dentro del último cuarto del siglo II a.C.

Junto a estas importaciones aparecen también producciones de cerámica común del ámbito púnico-gaditano: una cazuela de cocina de borde ranurado (fig. 12: 1), clasificada recientemente con la forma GDR 11.1.1 (Sáez 2005: 162-163), y un borde de jarra con arranque de asa similar a la forma GDR 10.2.1 (fig. 7: 3), cuya fabricación debe situarse también en la bahía de Cádiz (Sáez 2005: 160-161). El repertorio local, por su parte, está representado principalmente por los lebrillos de grandes dimensiones (entre 45 y $50 \mathrm{~cm}$. de diámetro), cuyos 


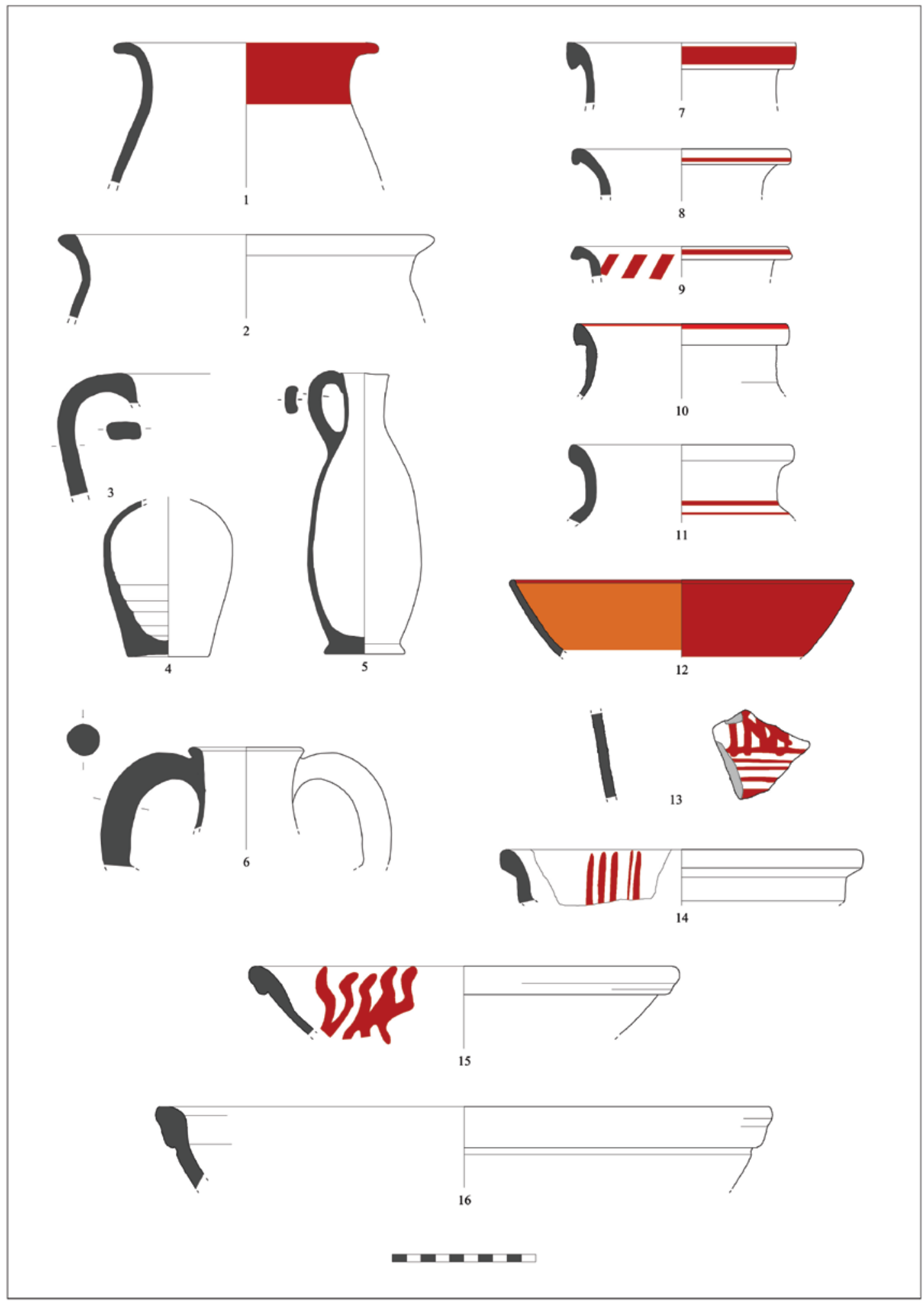

Figura 7. Cerámica común de producción local (fines siglo II y siglo I a.C.). Urnas indeterminadas: 1-2, 6 y 13; jarras de tradición gaditana: 3 y 4, 5 (prototipo de Cádiz); urnas globulares: 7-11; cuencos: 12; lebrillos: 14-16. 
bordes adquieren ya el perfil robusto, con secciones redondeadas o subrectangulares, que caracterizará a las producciones tardías (fig. 5: 7). Lo mismo puede decirse de un ejemplar de menor tamaño $(24 \mathrm{~cm}$. de diámetro), decorado con una serie de trazos verticales de color rojizo dispuestos de forma irregular al interior del recipiente (fig. 7: 14). Se trata, como veremos, de una variante propia del Bajo Guadalquivir que encontramos sobre todo en contextos de época tardorrepublicana. Las urnas de cuello corto y los cuencos de casquete esférico siguen también, con algunas variantes, los esquemas formales y decorativos heredados del periodo turdetano. Entre las primeras hacen acto de presencia los ejemplares de borde engrosado al exterior, de sección triangular o trapezoidal, decorados con una sencilla banda de color rojizo (fig. 7: 8). Las urnas globulares con asas laterales (forma IX de Escacena) están igualmente presentes en este contexto con dos ejemplares, aunque sólo se han podido identificar las asas. Por su parte, los cuencos se reducen a la variante más sencilla, de borde redondeado, mientras que los especimenes de paredes verticales, sin decoración pintada (fig. 4: 6), prefiguran ya la forma de los cuencos de engobe claro que pasarán a integrarse en el repertorio de las cerámicas comunes romanas durante el siglo I d.C. (Serrano 1995: 237-238).

La anulación definitiva de esta estructura se producirá durante las primeras décadas del siglo I a.C. Corresponden a este episodio una serie de vertidos superpuestos de carácter doméstico, muy heterogéneos en cuanto al material aportado. El primero de ellos (UE 363-370) ofreció un borde de mortero campano del tipo Emporiae 36.2, cuya producción se extiende entre la segunda mitad del siglo II a.C. y la segunda mitad de la siguiente centuria, así como un asa y algunos fragmentos amorfos de un ánfora ibicenca que podría identificarse con el tipo 8.1.3.2 o 8.1.3.3 de Ramón. El primero se fecha entre el 200 y el 120 a.C. (Ramón 1995: 224), mientras que la cronología del segundo se sitúa entre el 120-100 a.C. y el 50-75 d.C. (Ramón 1995: 225). Por lo demás, nos encontramos algunas de las formas habituales del repertorio común local mezcladas con material residual, cerámicas a mano principalmente. El resto de los depósitos apenas aportaron testimonios significativos.

La Estructura 6 es la última construcción de época romano-republicana. Está formada ya por un muro de ladrillos (UE 315), al que se asocian dos pavimentos superpuestos realizados en opus signinum. La cimentación de este muro (UE 364) proporcionó un conjunto residual de restos cerámicos, entre los que se encontraban presentes un bol de cerámica Campaniense A, correspondiente a la forma Lamb. 27 a-b, el pivote y un asa de ánfora Dressel 1, así como los bordes de un cuenco, una urna de pequeño formato y un lebrillo de tradición turdetana. El único contexto que ofreció material diagnosticable fue un nivel de reparación del segundo de los pavimentos que conformaban la estancia (UE 366). En su interior se halló un borde de ánfora ibicenca del tipo PE 25 de Ramón (1991: 119-122) y otro borde de Haltern 70 de morfología tempranoaugustea, que nos sitúa ya en torno al cambio de Era.

\section{Alemanes 25 (2124)}

En el $n^{\circ} 25$ de la calle Alemanes, frente al Patio de los Naranjos de la catedral de Sevilla, se excavó en 2006 un área de unos $100 \mathrm{~m}^{2}$ en la que fue documentado un sector extramuros situado en la zona portuaria de la ciudad tardorrepublicana. La estratigrafía, relativamente simple desde el punto de vista constructivo, se inaugura con un par de depósitos superpuestos (UU. EE. 184 y 185) sobre los que se dispuso un muro de ánforas colocadas en vertical. Las ánforas, cuya reconstrucción está aun pendiente, corresponden casi en su totalidad a la forma gadirita tardopúnica 7.4.3.3 y se encontraban rotas por debajo de la boca. Estos estratos "fundacionales" presentan fragmentos de ánforas de los tipos 7.4.3.3, 9.1.1.1, Pellicer D, LC 67, Haltern 70-Clase 24 y Dressel 7-11. En virtud del repertorio de la vajilla de barniz negro del círculo de las B (Lamb. 1, 1-8, 4 y 33 b), de la cerámica itálica común y de cocina (Vegas 14 y Luni 1) y de las formas de paredes finas (Mayet I), los depósitos pueden ser datados en los momentos finales de la época republicana, inmediatamente antes de la recepción de las primeras sigillatas itálicas que alcanzaron la ciudad en tiempos tempranoaugusteos, lo que nos llevaría a una fecha entre 50/40 y 25 a.C. para estos contextos, es decir, dentro del tercer cuarto del siglo I a.C.

Los niveles de amortización de este conjunto anfórico (UU.EE. 179 y 164) presentan un repertorio similar al anterior, compuesto por T-7.4.3.3, Pellicer D, Lamboglia 2 y Dressel 7-11 de las bahías de Cádiz y Algeciras. Un fragmento atípico acanalado de ánfora ibicenca (probablemente una PE 18) procedente de la UE 164 completa el elenco destinado al transporte, que se acompaña de barnices negros calenos (Lamb. 1, 3, 5 y 33 b), paredes finas de la forma Mayet 1 y ollas comunes de importación itálica de borde entrante y plano (COM-IT 2d), lo cual nos sitúa en una fecha similar a los niveles anteriores, e indica que la construcción 


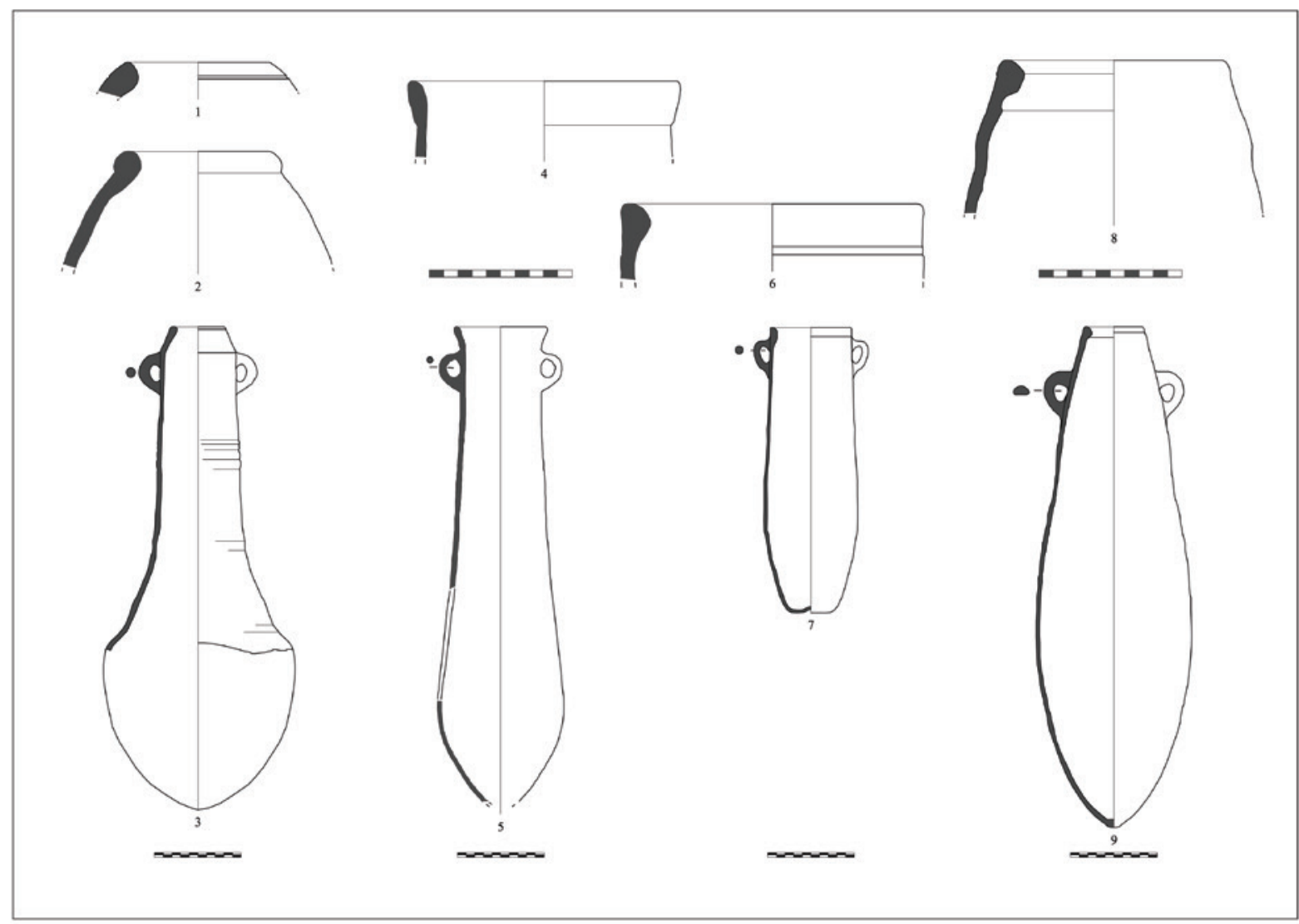

Figura 8. Ánforas de producción púnico-gaditana. T-12.1.1.1 y T-12.1.1.1/2: 1 y 2, 3 (prototipo de Cádiz); T-8.2.1.1: 4, 5 (prototipo de Sevilla); T-9.1.1.1: 6, 7 (prototipo de Cádiz); T-8.1.1.2: 8, 9 (prototipo de Cerro Naranja).

y amortización del "muro de ánforas" sucedió en un lapso breve de tiempo, anterior en cualquier caso a la recepción de las primeras sigillatas itálicas.

Las formas de tradición turdetana halladas en estos contextos son los lebrillos de cuello estrangulado, algunos de ellos con chorreones de pintura sobre el borde y motivos de retícula en el interior (fig. 7: 15), así como urnas de borde triangular y decoración de líneas pintadas en rojo tanto en el borde como bajo el cuello (fig. 7: 7). Las cerámicas de cocina turdetanas se componen básicamente de ollas de borde vuelto, realizadas en ambiente reductor y con abundante desgrasante. Conviven con tipos de influencia itálica, como las ollas de borde entrante y tendencia horizontal, en cocción oxidante. Las pequeñas jarras de boca moldurada, también de tradición itálica, parecen generalizarse en este momento.

Sobre la amortización del "muro de ánforas" se cimentó un muro de aparejo irregular cuya zanja de construcción presenta un material en gran medida similar al anterior, pero en el que ya están presentes las sigillatas itálicas y gálicas de las formas Drag. 18a y 29a, lo que permite situar su construcción en época julio-claudia, siendo el barniz negro del contexto probablemente residual.

\section{NOVEDADES TIPOLÓGICAS Y FUNCIONALES EN EL ÁMBITO LOCAL}

A partir de finales del siglo IV a.C. se aprecian algunos cambios significativos en la composición y morfología de los repertorios turdetanos, con la generalización de algunos tipos ya conocidos y la aparición de otros nuevos. Estos cambios son aún más evidentes entre finales del siglo III y principios del I a.C. y afectan sobre todo a determinadas formas de la cerámica común y pintada. En este proceso cabe ver, por un lado, la influencia del ámbito púnico, a través del cual se incorporan a las producciones locales algunas soluciones 
formales procedentes del mundo helenístico. Por otro lado, tras la conquista romana hacen su aparición nuevas variantes recientemente identificadas, así como, sobre todo, formas y motivos decorativos de clara raigambre ibérica. La arribada de las primeras producciones itálicas -no sólo vajilla de lujo, sino también cerámica de cocina- y la reactivación del comercio con el Levante determinará la configuración de un repertorio sumamente original en el que tradición e innovación se dan la mano en los mismos recipientes.

\section{Cerámica de transporte: ánforas}

En estos momentos el ánfora local por excelencia es la forma D de Pellicer (García y González 2007: 555) (fig. 2: 12). Este recipiente pudo haber sido, en realidad, el resultado de una evolución del ánfora Pellicer B-C, que a finales del siglo IV y probablemente por influencia púnica, habría adoptado el perfil cilíndrico y alargado que caracteriza a estos envases (Ferrer 1995: 803). Aunque el debate sobre el posible origen púnico o turdetano de las Pellicer D se encuentra aún abierto (Niveau de Villedary 2002: 241), lo que parece fuera de toda duda es que su producción se extendió rápidamente hacia el interior del valle y la antigua desembocadura del Guadalquivir, como se desprende de los ejemplares documentados en un vertido de alfar excavado recientemente en la ciudad de Carmona (Ortiz y Conlin, e.p.). La forma parece surgir a finales del siglo IV o inicios del III a.C. (Niveau de Villedary 2002: 240) y perdura al menos hasta finales del siglo I a.C. Durante este tiempo se observa una tendencia generalizada a la simplificación de los bordes, que a mediados del siglo II a.C. apenas se diferencian ya de la pared más que por un ligero engrosamiento en su extremo (fig. 2: 9-11), así como una diversificación de las pastas, que apuntan a una enorme variedad de talleres y procedencias. Las últimas producciones, que convivirán con las primeras ánforas béticas, se caracterizan por presentar un labio plano de tendencia horizontal y totalmente indiferenciado, como puede apreciarse en los ejemplares provenientes de los niveles republicanos de la calle Argote de Molina o de la excavación de la calle Alemanes ( $\mathrm{su}$ pra). Algunas de estas ánforas guardan claras analogías con los especimenes registrados en la costa portuguesa y denominados comúnmente "tipo Castro Marim 1". En estos casos las pastas apuntan también a un origen sudpeninsular, por lo que podría tratarse de una evolución tardía del tipo realizado en los alfares del área del Estrecho (Arruda 2001: 77-78).

\section{Cerámica de cocina}

Un fenómeno particular de los contextos tardorrepublicanos de Sevilla y, en general, del Bajo Guadalquivir es la continuidad morfológica del repertorio local de cocina. Desde el siglo IV a.C. al menos, éste se hallaba compuesto fundamentalmente por las ollas globulares a torno, derivadas de formas similares orientalizantes realizadas a mano (fig. 3: 7-14), a lo que habría que unir los nuevos morteros de tradición púnica (fig. 3: 1-6). Las primeras se caracterizan, como hemos podido ver, por su factura grosera, con pastas oscuras y borde engrosado, de sección oval o almendrada y de tendencia vertical, o ligeramente pronunciado al exterior (García y González 2007: 556-557). No obstante, a pesar de esta continuidad formal y funcional, pueden señalarse a partir de fines del siglo II a.C. algunas novedades que afectan al menaje doméstico. Así pues, los morteros se "romanizan", desarrollando formas similares a la itálica Emporiae 36.2 (fig. 12: 17), y dando de este modo inicio a una serie de morteros de tipología romana y producción sudhispana ampliamente exportados (Pinto y Morais 2007), cuya producción alcanzará la época imperial avanzada (infla). Por su parte, las ollas desarrollan bordes vueltos de sección triangular y mayor altura que en períodos precedentes, mientras que mantienen su peculiar tecnología de cocción reducida a baja temperatura e inclusión de abundantes desgrasantes, fundamentalmente cuarzo fino y medio y mica plateada.

\section{Cerámica común}

Ya hemos hecho referencia en alguna ocasión al proceso de conformación de la vajilla común turdetana, en la que apenas se aprecian cambios significativos, tanto a nivel morfológico como decorativo, hasta la conquista romana (García Fernández 2007: 130; García y González 2007: 549-550). Por un lado, asistimos a la fosilización de un número muy limitado de formas, herederas del repertorio orientalizante y con una clara funcionalidad doméstica. Nos referimos principalmente a los cuencos (fig. 4: 1-13 y 23-26), platos (fig. 4: 14-22), lebrillos (fig. 5: 1-5), urnas y vasos de almacenamiento (fig. 6: 1-5 y 8-9). Por otro lado, se observa una tendencia generalizada a la reducción de la decoración, que se limita a bandas anchas o líneas de color rojizo, combinadas en ocasiones con líneas negras o trazos irregulares del mismo color. Paralelamente, se produce una mejora en la calidad de las pastas y en los hornos, dando 


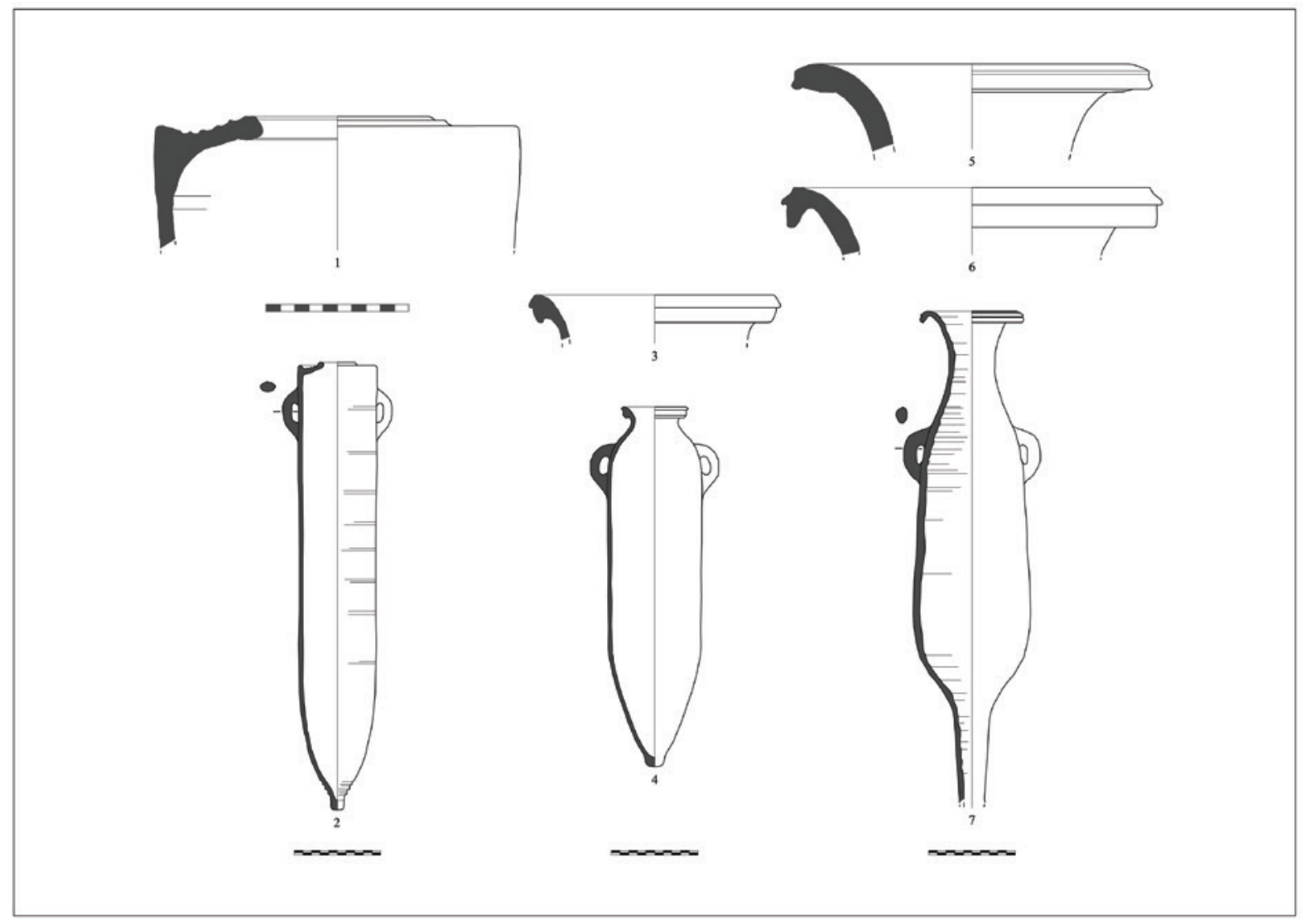

Figura 9. Ánforas de producción centromediterránea: T-5.2.3.1: 1, 2 (prototipo); T-7.2.1.1: 3, 4 (prototipo); T-7.4.3.0 (imitación gaditana): 5 y 6, 7 (prototipo de Cádiz).

lugar a recipientes muy compactos, de fractura irregular, que irán perdiendo paulatinamente el nervio de cocción que caracteriza a las producciones más antiguas. A partir de finales del siglo III a.C. existe ya un claro predominio de la cocción oxidante frente a la cocción alterna o reductora, que se irá acentuando conforme nos acerquemos al cambio de Era.

Por lo que respecta a la composición de los ajuares, se generalizan a partir de finales del siglo IV a.C. nuevos tipos que gozarán de gran éxito en las siguientes centurias, como es el caso de las urnas con baquetón (fig. 6: 6-7), los cuencos-lucernas (fig. 4: 27-34), los vasos caliciformes de pequeño formato, también conocidos como "vasos para beber" (fig. 5: 11-15) y, algo más adelante, las urnas globulares -en ocasiones con asas laterales- (fig. 6: 10-14) y los vasos tulipiformes (fig. 5: 8-10) o "escudillas" (véase Ferrer y García 2008: 208 ss). Se trata, en este caso, de un recipiente abierto de perfil quebrado, con la carena en la parte central del cuerpo y borde indiferenciado o ligeramente exvasado. Suele llevar tres o más filetes pintados de rojo en la superficie externa del vaso, por encima de la carena (Ferrer y García 2008: 209). Frecuentemente se ha aducido un origen foráneo para alguno de estos tipos, sobre todo para los cuencos-lucerna, muy similares a los pequeños cuencos áticos de barniz negro que arribaron a las costas de la Península Ibérica a finales del siglo V a.C. (Luzón 1973: 38-39), y para los "vasos para beber" o caliciformes (Luzón 1973: 39). Sin embargo, en todos los casos se trata de formas presentes de alguna manera en la matriz orientalizante (véase, en general, Escacena 1987). Por otro lado, frente a la atonía generalizada que afecta al servicio de mesa, es posible apreciar el desarrollo a partir de mediados del siglo II a.C. de nuevas variantes de urnas y lebrillos que permiten individualizar claramente las producciones de época romano-republicana.

Las urnas mantienen los rasgos morfológicos generales heredados del vaso "a chardón" orientalizante: cuerpo globular o bitroncocónico, cuello acampanado 
o de tendencia cilíndrica, que puede arrancar en ocasiones de una carena, labios exvasados con diferentes soluciones y fondo rehundido o indicado. No obstante, a finales del siglo III a.C. se invierte la tendencia observada en la decoración y comienzan a introducirse motivos pintados de mayor complejidad, como reticulados, líneas de agua, trazos verticales, semicírculos y círculos concéntricos (fig. 6: 5), que se extienden también a las urnas con baquetón. Esta novedad no afecta a todas las producciones, pero sí es mayoritaria en los ejemplares documentados en contextos funerarios, como ha podido comprobarse en algunas urnas procedentes de la necrópolis de Carmona (Escacena y Belén 1994: 249 ss). La aparición tardía de urnas cinerarias con decoración pintada podría estar trasluciendo una perduración de prácticas ancestrales entre las poblaciones locales de origen semita, o bien la llegada de nuevos contingentes procedentes, en este caso, del área ibérica, ya sea en el marco de la II Guerra Púnica o en las posteriores contiendas bélicas que tuvieron lugar en la provincia Ulterior ${ }^{5}$.

Igualmente llamativa se nos antoja la aparición a finales del siglo II a.C. de una nueva variante en pastas más claras y con engobe exterior color crema (fig. 7: 7-11). Se caracteriza por presentar un cuello corto de tendencia cilíndrica y bordes muy desarrollados de sección triangular o trapezoidal, ligeramente redondeados en su cara externa y en ocasiones caídos. La decoración, en caso de existir, se limita a una línea más o menos estrecha de color rojizo situada en el cuello o justo en la parte exterior del borde. Su uso se generaliza en el siglo I a.C. y perdura, al menos, hasta época flavia, aunque no se ha llevado a cabo hasta la fecha un seguimiento exhaustivo de estas producciones tardías en el ámbito de la Baja Andalucía.

En los lebrillos se observa una doble tendencia: primero la adopción de formas evolucionadas de gran formato y, posteriormente, la incorporación de decoración interior. Por lo que respecta a su forma, los lebrillos de época republicana se caracterizan por presentar un perfil más abierto, un diámetro sensiblemente mayor a los de sus predecesores (en ocasiones superior a $50 \mathrm{~cm}$.) y un estrangulamiento menos marcado en el cuello. Sus bordes, engrosados al exterior, desarrollan perfiles cuadrangulares, ovalados o trapezoidales, que serán propios

5. Según Escacena (2000: 236), el lote de urnas de Carmona pudo contener los restos de las primeras generaciones de colonos itálicos instalados en la ciudad, aunque no deja clara la razón que llevó a sus usuarios a emplear motivos decorativos ajenos a su cultura y más relacionados con las cerámicas de la Alta Andalucía. de este periodo, llegando al menos al siglo I d.C. (fig. 5: 6-7). No obstante, lo más interesante de estas nuevas producciones es la decoración presente en algunos ejemplares documentados en el Bajo Guadalquivir (fig. 7: 14-15). Se trata de una manifestación doblemente insólita ya que, por un lado, la decoración se coloca en el interior del recipiente, frente a la tendencia habitual de situarla en el exterior; no olvidemos además que la decoración pintada va reduciéndose desde finales del siglo IV, siendo ya testimonial en el siglo III a.C. (Bandera y Ferrer 2002: 131; García y González 2007: 552). Por otro lado, los motivos representados son prácticamente inéditos en el área turdetana y remiten directamente a las producciones de la Alta Andalucía. Consisten principalmente en trazos irregulares verticales u horizontales, en algunos casos paralelos, flameados, motivos ondulados horizontales, conocidos como "costillas" o "costillares" y líneas de agua en ambos sentidos, correspondiendo estos dos últimos a los motivos 38 y 42 de Escacena (1987: 987 y 1012). La mayor parte de los ejemplares registrados se concentran en Sevilla, Carmona o Alcalá del Río, la antigua Ilipa Magna. Su ausencia en núcleos tan emblemáticos como Itálica podría estar indicando una producción muy localizada, probablemente en los talleres de Carmona, donde se han identificado algunos ejemplares con fallos de cocción en vertidos de hornos (Ortiz y Conlin, e.p.).

\section{NOVEDADES TIPOLÓGICAS Y FUNCIONALES: IMPORTACIONES DEL ÁMBITO PÚNICO}

En torno al siglo IV a.C. se detecta la llegada al puerto de Sevilla de nuevas importaciones procedentes del ámbito púnico, coincidiendo con el inicio de un nuevo periodo de bonanza para la ciudad tras la fase de letargo que había supuesto la crisis del mundo orientalizante (Ferrer y otros, e.p.). Se trata de un proceso generalizado de reactivación económica y comercial que afecta por igual a las localidades ribereñas del Lacus Ligustinus y del antiguo estuario del Guadalquivir. En un principio estas importaciones se limitaban a los productos envasados en las ánforas, sobre todo aceite y conservas de pescado, aunque posteriormente se introducirán también algunos recipientes relacionados con la preparación y servicio de alimentos. Es el caso, como se verá a continuación, de los morteros, las grandes fuentes, las ollas y las cazuelas con borde ranurado, así como la vajilla de semilujo tipo "Kouass", que sustituirá a partir del siglo III a.C. a las importaciones áticas. 

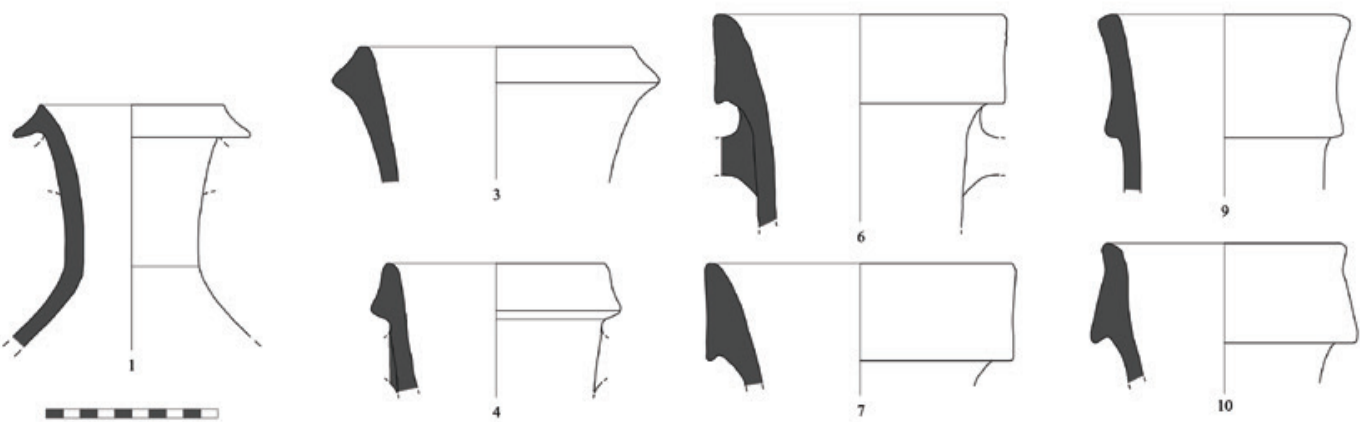

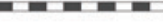
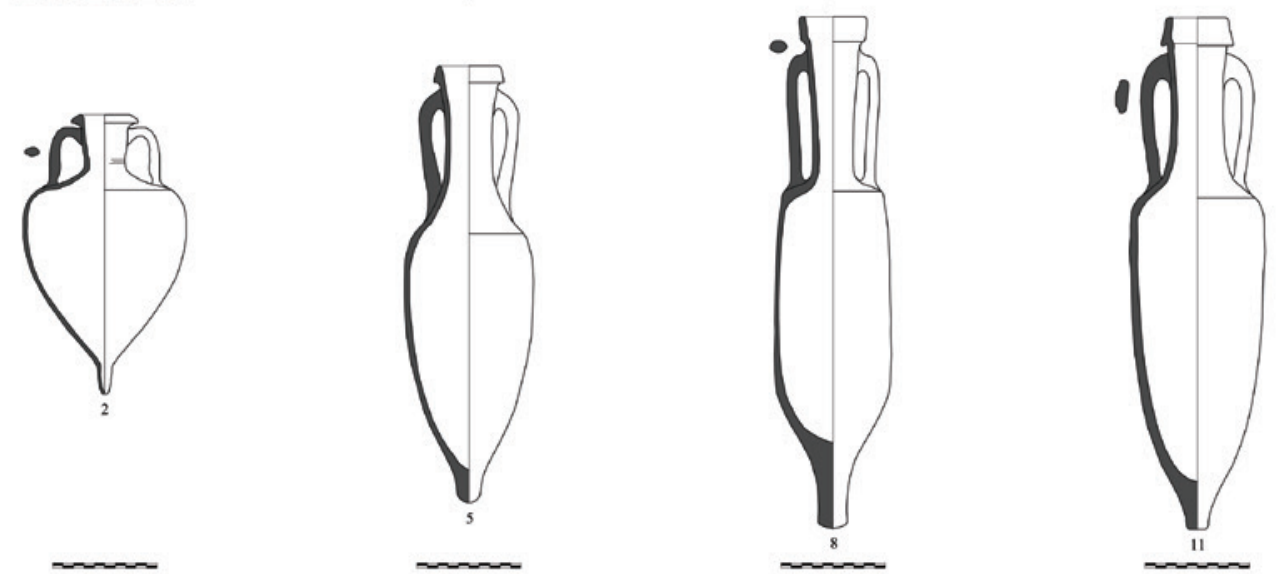

Figura 10. Ánforas de producción itálica. Grecoitálica: 1, 2 (prototipo); Dressel 1A: 3 y 4, 5 (prototipo); Dressel 1B: 6 y 7, 8 (prototipo); Dressel 1C: 9 y 10, 11 (prototipo).

\section{Cerámica de transporte: ánforas}

Las primeras ánforas que arriban al puerto de Sevilla corresponden al grupo de las Mañá-Pascual A4, especialmente las variantes T-11.2.1.3 y $\mathrm{T}-11.2 .1 .4$, cuya producción se sitúa entre finales del siglo VI e inicios del IV a.C. (Ramón 1995: 235-236), y la T-12.1.1.1 (Ramón 1995: 238), que comienza a fabricarse en la segunda mitad de esta centuria (fig. 8: 1-2). Están destinadas al envasado y comercialización de salazones y salsas saladas, lo que explica que sus centros de producción se concentren principalmente en el área del Estrecho de Gibraltar (de Frutos y Muñoz 1996: 142).

A finales del siglo IV a.C. empiezan a llegar también los primeros envases procedentes de la campiña gaditana. Se trata del ánfora tipo "Tiñosa" o T-8.1.1.2 (fig. 8, 8), destinada probablemente al transporte de aceite (véase Carretero 2007). Su producción se extiende a lo largo del siglo III, aunque no parece alcanzar el II a.C. Otra ánfora típica de este momento es la
T-8.2.1.1 o "Carmona" (fig. 8: 4-5), según la clasificación de Rodero (1991). En este caso su fabricación se concentra principalmente en los talleres de la bahía de Cádiz, aunque también pudiera extenderse hacia el interior (Carretero 2004: 427-428). Por lo que respecta al contenido, tanto su forma como las marcas registradas hasta la fecha parecen sugerir que se trataba también de un ánfora salazonera, si bien no se han realizado aún análisis físico-químicos que aporten resultados concluyentes (Sáez y otros 2004: 113). Como ya se ha indicado más arriba, los inicios de este tipo pueden situarse también el siglo IV, aunque su producción no se generalizará hasta el siglo III, perdurando durante prácticamente todo el siglo II a.C. (Sáez y otros 2004: 123).

Las ánforas tipo "Carmona" serán paulatinamente sustituidas desde finales del siglo III o inicios del II a.C. por un envase de similares características, aunque de menor altura y base plana, conocidas comúnmente como Campamentos Numantinos (fig. 8: 6) y clasificadas años después por Ramón dentro del tipo 9.1.1.1 
(Ramón 1995: 226-227). Constituyen una continuación del ánfora tipo "Carmona" tanto a nivel formal como en lo relativo a su contenido, que debió ser sin duda pescado salado. Su cronología iría desde inicios del siglo II hasta mediados del I a.C. (Carretero 2004: 433434), conviviendo ya con los primeros contenedores de tradición itálica y las imitaciones de ánforas norteafricanas (Sáez 2008b: 647).

Por lo que respecta a estas últimas, los únicos ejemplares registrados en Sevilla en contextos de ocupación corresponden al cuarto superior de un ánfora tipo Mañá D (T-5.2.3.1) y otra del tipo Mañá C2 (T-7.2.1.1), procedentes de la calle Argote de Molina (fig. 9, 1 y 3). Su llegada habría que situarla en un momento muy concreto, marcado por la presencia cartaginesa y la posterior Guerra Púnica, entre finales del siglo III e inicios del II a.C. No es casual, por tanto, que coincida en el tiempo con la introducción -lenta pero paulatina- de un nuevo menaje de cocina representado por las cazuelas de borde ranurado y los morteros de tradición centromediterránea.

A partir de finales del siglo II a.C. las ánforas T-8.2.1.1 y T-9.1.1.1 comparten las redes de distribución con las imitaciones locales del tipo Maña C2 (fig. 9: 5-6), correspondientes a los tipos 7.4.3.1 y 7.4.3.3 de Ramón (Sáez 2008b: 647). Su producción se extiende hasta el tercer cuarto del siglo I a.C. para desaparecer durante los primeros años del principado de Augusto (Ramón 1995: 213). Se trata una vez más de un ánfora salazonera, destinada en este caso probablemente a la comercialización de salsas de pescado.

A las formas mencionadas habría que añadir los especimenes de Pellicer D procedentes de la costa gaditana, cuya problemática se trató más arriba.

\section{La cerámica de cocina}

Dentro del repertorio doméstico la forma más habitual es la conocida como mortero, clasificada recientemente con la forma GDR 3.1.1 (Sáez 2005: 152). Se trata de un recipiente de paredes gruesas, bases amplias y bordes muy desarrollados. Las pastas contienen abundante desgrasante que aflora habitualmente a la superficie y en ningún caso portan decoración alguna. No se conoce exactamente ni su origen ni su función, aunque Luzón lo puso rápidamente en relación con recipientes de similares características existentes en la vajilla griega o helenística (Luzón 1973: 45). Sea como fuere, la forma no se generaliza en el ámbito púnico occidental hasta finales del siglo $\mathrm{V}$ o inicios del IV a.C.
(Ruiz Mata 1987: 311), distribuyéndose hacia el interior del valle y las campiñas del Guadalquivir en esta última centuria (Ruiz Mata y Niveau de Villedary 1999: 127). Los ejemplares más antiguos presentan un borde saliente de tendencia horizontal, aunque ligeramente convexo en su parte superior (fig. 3, 1-2); los más evolucionados, muy habituales en la ciudad de Sevilla (fig. 3: 4-5), poseen en cambio bordes más gruesos y redondeados, con un apéndice pronunciado en el extremo interior y amplias acanaladuras en la parte superior (Ruiz Mata 1987: 311; Sáez 2005: 152). Cabe la posibilidad de que estos recipientes fueran imitados en los talleres locales, como parece reflejar un ejemplar hallado en la estratigrafía de la calle Abades, decorado al interior con una amplia banda de color rojo vinoso (Jiménez y otros 2006: Lám. 3).

Excepcionales son, en cambio, los morteros de origen centromediterráneo. Aunque parecen formar parte de la misma tradición, se diferencian por presentar paredes más delgadas y el labio ligeramente caído, con una acanaladura más o menos pronunciada hacia el interior del borde que en ocasiones queda reducida a un apéndice o una carena. Se le ha atribuido el mismo cometido que a las producciones peninsulares, esto es, la preparación de alimentos y más concretamente la función de moler, triturar o incluso amasar los ingredientes (Martín y Roldán 2000: 1616). No obstante, es posible que los escasos ejemplares hallados en Sevilla (fig. 12: 2) respondan más bien a imitaciones realizadas en los talleres gaditanos, como se ha señalado recientemente para la mayor parte de los especimenes documentados en la propia ciudad de Cádiz (Sáez 2005: 153). Su distribución, eminentemente costera, no se inicia hasta finales del siglo III a.C. perdurando, como ya se ha señalado, hasta mediados de la siguiente centuria (Martín y Roldán 2000: 1619; Asensio 2001-2002: 306).

Coincidiendo con los inicios de la presencia cartaginesa arribarán también a los puertos del sur de la Península nuevos recipientes de cocina, relacionados en este caso con el uso habitual del fuego. Nos estamos refiriendo principalmente a las cazuelas y ollas de borde ranurado, realizadas con pastas poco depuradas y abundante desgrasante con cualidades refractarias. En ambos casos se trata de formas abiertas, base plana o redondeada y paredes finas y rectas, con una ligera tendencia a abrirse en las cazuelas. De hecho, su principal diferencia estriba en la relación entre el diámetro y la altura del recipiente: en las ollas la altura es igual o superior al diámetro, mientras que en las cazuelas el diámetro es siempre muy superior (Guerrero 1995: 6162). Cuentan generalmente con dos asas horizontales 


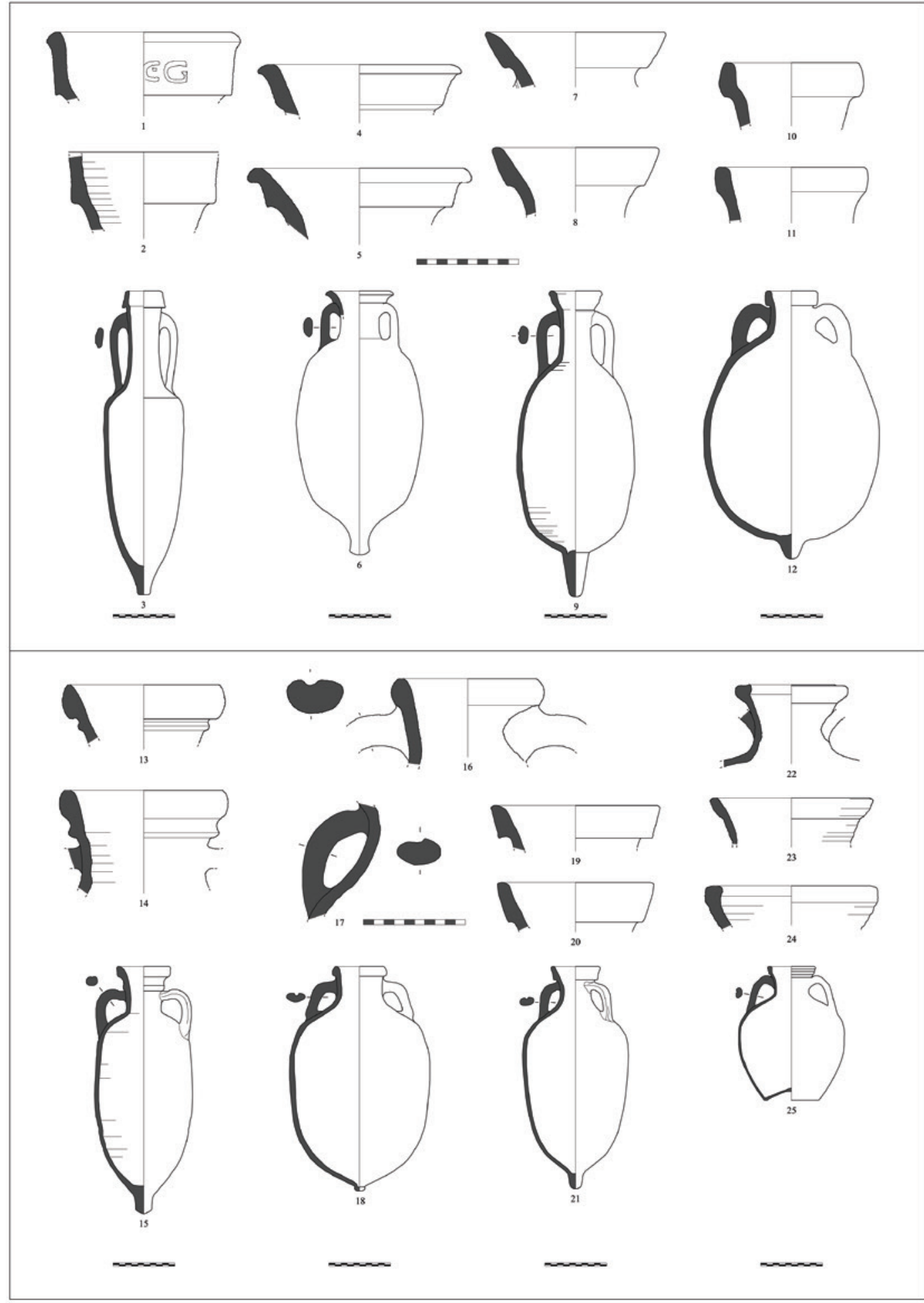

Figura 11. Ánforas itálicas de producción bética: Dressel 1C (imitación local): 1 y 2, 3 (prototipo); Dressel 7-11: 4 y 5, 6 (prototipo); Haltern 70: 7 y 8, 9 (prototipo); Oberaden 71/Dressel 20: 10 y 11, 12 (prototipo); LC 67: 13 y 14, 15 (prototipo); Oberaden 83: 16 y 17, 18 (prototipo); Haltern 70 small variant: 19 y 20, 21 (prototipo); tipo urceus: 22-24, 25 (prototipo). 
aplicadas bajo el borde o hacia la mitad del recipiente. Sin embargo, su rasgo más característico es la presencia de una acanaladura hacia el interior del borde, destinada a servir de apoyo a una tapadera. En este sentido y con base en su forma, se viene atribuyendo a las cazuelas la función de freír o adobar determinados alimentos, mientras que las ollas estarían dedicadas principalmente a la cocción (ibidem).

Aunque el uso de cazuelas con tapadera está atestiguado en Cádiz desde finales del siglo VI o inicios del V a.C. (Sáez 2005: 162), la generalización de esta forma no se producirá hasta finales del siglo III o inicios del II, coincidiendo con la llegada de prototipos ebusitanos y centromediterráneos, en los que se inspirarán ahora las producciones gadiritas (Niveau de Villedary 2001-2002: 283). Los escasos ejemplares documentados hasta ahora en Sevilla (fig. 12: 1) parecen corresponder a estas últimas (GDR 11.1.1) ${ }^{6}$, como demuestra la similitud en las pastas y tratamiento exterior, aunque no se descarta la aparición de especimenes importados. La forma perdura hasta las últimas décadas del siglo II, cuando comienza a verse paulatinamente reemplazada por las cazuelas itálicas del tipo Vegas 14, que serán también imitadas en los alfares locales del sur de la Península Ibérica (Sáez 2005: 163).

Otro tipo muy común en la bahía de Cádiz, que en ocasiones puede hallarse también en la ciudad de Sevilla (fig. 3: 15), es la olla de cocina de borde triangular (GDR 12.3.1), generalmente con una leve acanaladura en su parte exterior (Sáez 2005: 165). Nos encontramos de nuevo ante formas semicerradas, de cuello ancho y corto, paredes rectas, cuerpo de tendencia globular y pie indicado, levemente rehundido al interior. Presentan pastas groseras, con numerosos desgrasantes refractarios de pequeño y mediano tamaño, así como las superficies parcialmente quemadas por la acción del fuego (Niveau de Villedary 2001-2002: 283). En este caso parece tratarse de un tipo local, que tendría su origen en los talleres gadiritas en el siglo III a.C. Su producción se generaliza en la segunda mitad de esta centuria, perdurando hasta mediados del siglo II,

6. No obstante, A.M. Sáez apunta la existencia de dos tipos de pastas distintas: una más tosca, con tonalidad marrón o grisácea y abundante desgrasante micáceo y cuarcítico de mediano-pequeño tamaño, por tanto más apta para estar expuesta al fuego; y otra menos frecuente, compuesta por pastas más depuradas y cocción predominantemente oxidante, destinadas en cualquier caso a otras actividades domésticas (Sáez 2005: 163). A estas últimas podrían corresponder, como señala el autor, los ejemplares hallados en los pozos de la necrópolis tardopúnica de Cádiz, con una función probablemente ritual (Niveau de Villedary 2001-2002: 283-284). cuando probablemente fueron sustituidas por los nuevos recipientes de prototipo centromediterráneo (Sáez 2005: 165). La función, una vez más, podría haber sido la cocción de alimentos, aunque su frecuente aparición en la necrópolis gaditana permite pensar también en un uso ritual (Niveau de Villedary 2006: 57).

\section{Servicio de mesa}

Nos centraremos en este apartado en la cerámica de barniz rojo tipo "Kouass", dadas las enormes concomitancias que mantiene la vajilla común púnico-gaditana con las producciones del área turdetana ${ }^{7}$. Sin embargo, no podemos pasar por alto la aparición a finales del siglo III a.C. de un tipo de jarra de mesa ausente anteriormente en los repertorios locales del Bajo Guadalquivir (fig. 7: 3). Coincide con la Forma GDR 10.2.1 definida recientemente por A.M. Sáez (fig. 7: 5), cuya producción se ha fijado en los alfares de la bahía de Cádiz entre mediados del siglo III y mediados del II a.C. (Sáez 2005: 160). Se trata de un recipiente de medianas dimensiones, cuerpo con tendencia cilíndrica ligeramente abombado, cuello largo y estrecho, base diferenciada y bordes simples sin vertedor. Presenta un asa corta de sección rectangular o subrectangular, con una ligera acanaladura en la cara interior, que arranca a la altura del borde para descansar bajo el cuello. Constituye una auténtica novedad en el servicio de mesa turdetano no exenta de interés, ya que desde época orientalizante apenas se documentan jarras en contextos domésticos, sin que sepamos hasta el momento qué recipiente pudo cumplir esta función durante ese tiempo (Jiménez y García 2006: 142). En cualquier caso, su presencia en la ciudad de Sevilla no deja de ser circunstancial, como ocurre también con los platos de pescado de tradición púnica, correspondientes al subtipo II-D de Escacena (1987: 251), cuyo uso es visiblemente minoritario en relación con el "plato turdetano" (Escacena II-B) de perfil quebrado y borde vuelto.

Por lo que respecta a la cerámica de "Kouass", ésta se encuentra pobremente representada en los contextos exhumados hasta la fecha, sobre todo si la comparamos con otras producciones del ámbito púnico gaditano, como las ánforas o la cerámica de cocina. En

7. De hecho, muchas veces es difícil diferenciar el repertorio morfológico propiamente púnico del turdetano, sobre todo cuando nos referimos a la cerámica a torno común y pintada, lo que resulta hasta cierto punto lógico si tenemos en cuenta que ambas tradiciones beben de una misma matriz, que no es otra que la cerámica a torno de época orientalizante (Ferrer y García 2002: 146). 


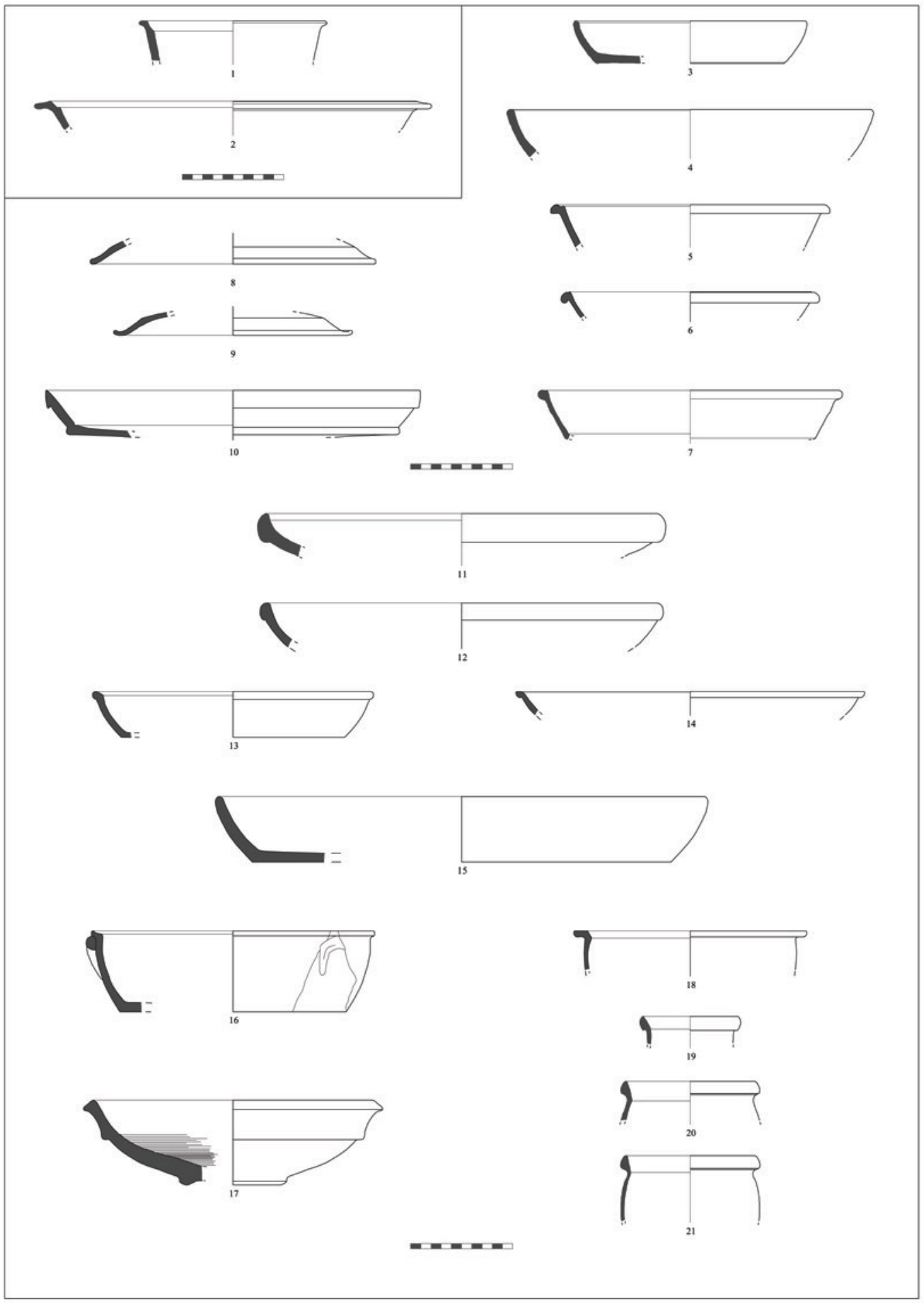

Figura 12. Cerámica de cocina de tradición itálica. Platos de borde bífido Vegas 14: 3 y 4; Emporiae 158, 15: 5; Torre Tavernera 4, 10: 6; Argote 3.694: 7; tapaderas Celsa 80, 7056: 8 y 9; sartén Celsa 84, 13596: 10; cazuelas en rojo pompeyano Luni 1: 11 y 12; Luni 2/4: 13 y 14; Luni 5: 15; plato con asas horizontales Burriac 549: 16; mortero Emporiae 36, 2: 17; cazuela Celsa 79, 28: 18; ollas Vegas 2: 19-21. Cerámica de cocina de tradición centromediterránea. Cazuela GDR 11.1.1: 1; mortero Lancel 131: 2. 
la mayor parte de los casos lo único que conservamos son fragmentos atípicos, mientras que los bordes $\mathrm{y}$ fondos identificados se ciñen exclusivamente a copas y platos de pescado: formas IX y II de Niveau, respectivamente (fig. 4, 33-34). Esta situación puede responder, por un lado, a la propia casualidad, sobre todo teniendo en cuenta lo limitado del registro documentado, ya que la vajilla tipo "Kouass" sí aparece con relativa frecuencia en otros núcleos del Bajo Guadalquivir, como Itálica, Cerro Macareno o Alcalá del Río (Ferrer y García 2007: 122). Sin embargo, no hay que olvidar que la antigua Spal y su entorno se ubicaban en el "segundo círculo" de distribución de esta vajilla, es decir, en aquellas zonas que fueron abastecidas mayoritariamente por otros talleres, como le ocurre por ejemplo a Villaricos, o donde la cerámica importada sólo aparece de forma esporádica como bien de lujo, sin llegar a sustituir al repertorio común de tradición local (Niveau de Villedary 2003: 243). En este último caso lo que se observa es una demanda selectiva de ciertas formas y la total ausencia de otras (ibidem); un fenómeno que podría responder, como veremos, a una adaptación de la vajilla gaditana a los hábitos de consumo de las comunidades interiores del golfo Tartésico, donde el uso de la cerámica ática y posteriormente helenística nunca llegó a generalizarse completamente entre la población.

\section{NOVEDADES TIPOLÓGICAS Y FUNCIONALES: IMPORTACIONES DEL ÁMBITO ITÁLICO}

\section{Cerámica de transporte: ánforas}

La presencia de las ánforas itálicas es una constante en las estratigrafías sevillanas de época romanorepublicana desde mediados del siglo II a.C. al menos (Grecoitálica del tipo A de Will del nivel 25 de Argote de Molina), pero no será hasta los años finales de la centuria cuando se constate una importación más numerosa de ánforas vinarias (fig. 10: 1). Los contextos $372 \mathrm{y}$, sobre todo, 371 de la calle Alemanes arrojan los primeros conjuntos relativamente abundantes de Dressel 1A antiguas de procedencia campana, con las características pastas volcánicas y la pared exterior engobada en amarillo (fig. 10: 3-4). El tipo, con una cierta variedad de perfiles de bordes, siempre de sección triangular, y con fondos cortos y redondeados no muy habituales en la forma, se mantiene (Cuesta del Rosario), e incluso es mayoritario, en los años iniciales del siglo I a.C. en los niveles 18-20 de Argote de
Molina, acompañado ahora por las Dressel 1B y C con pastas no campanas, aunque en cualquier caso itálicas (fig. 10: 6-7 y 9-10). Las Dressel 1B y C serán las variantes del tipo presentes en Sevilla en el último tercio de la centuria, como testimonian los ejemplares de las calles Alemanes y Fabiola. El mismo fenómeno de pervivencia de Dressel 1B y C hasta momentos finales del siglo I a.C. (incluso ya augusteos) se constata en otros contextos de la región como los de las calles Santa Verania de Alcalá del Río (Cervera y otros 2007) y Dr. Fleming en Carmona (Ortiz y Conlin, e.p.). En cualquier caso, el tipo Dressel 1 es siempre minoritario en niveles de fines del siglo I a.C.

Junto a las ánforas tirrénicas, hay que considerar la presencia en contextos tanto de inicios (nivel 20 de Argote de Molina) como de finales (UE 164 de Alemanes) del siglo I a.C. de ánforas adriáticas del tipo Lamboglia 2. En el primer caso las pastas, muy depuradas, apuntan tal vez a un origen apulo, mientras que en el segundo encontramos ejemplares con esta misma arcilla y con otra más oscura en la que se observan pequeñas inclusiones de nódulos rojos, tal vez óxido de hierro, lo que parece característico de las producciones noradriáticas.

\section{Cerámica de cocina itálica}

Desde principios del siglo I a.C. se observa en algunos contextos de consumo, como puede ser el caso de la calle Argote de Molina, la presencia de cerámicas de cocina de importación itálica. La morfología de éstas es a veces análoga a la que presentan las vajillas tradicionales: ollas del tipo Vegas 2 (fig. 12: 19-21), lo que parece indicar una función similar en los ámbitos domésticos; pero los tipos más frecuentes corresponden no a ollas, sino a cazuelas de los tipos Vegas 14 (fig. 12: 3-4) y Celsa 79/28 (fig. 12: 18), lo que, junto al inicio de la recepción de platos para horno del tipo Luni 1 y Luni 2/4 en rojo pompeyano (fig. 12: 11-14), de sartenes Celsa 84.13596 (fig. 12: 10) y de tapaderas Celsa 80.7056 (fig. 12: 8-9), sugiere un cambio sustancial en la forma de preparación de los alimentos.

A lo largo del siglo I a.C. la frecuencia de las ollas grises disminuye, si bien no desaparecen. En parte, son sustituidas por ollas de morfología itálica con borde entrante de tendencia horizontal. Se generalizan, además, los platos de engobe rojo pompeyano Luni 1 y las imitaciones de cazuelas itálicas de borde bífido (Vegas 14), que aparecen ahora acompañadas por cazuelas grises de fabricación y tipología locales, más profundas 


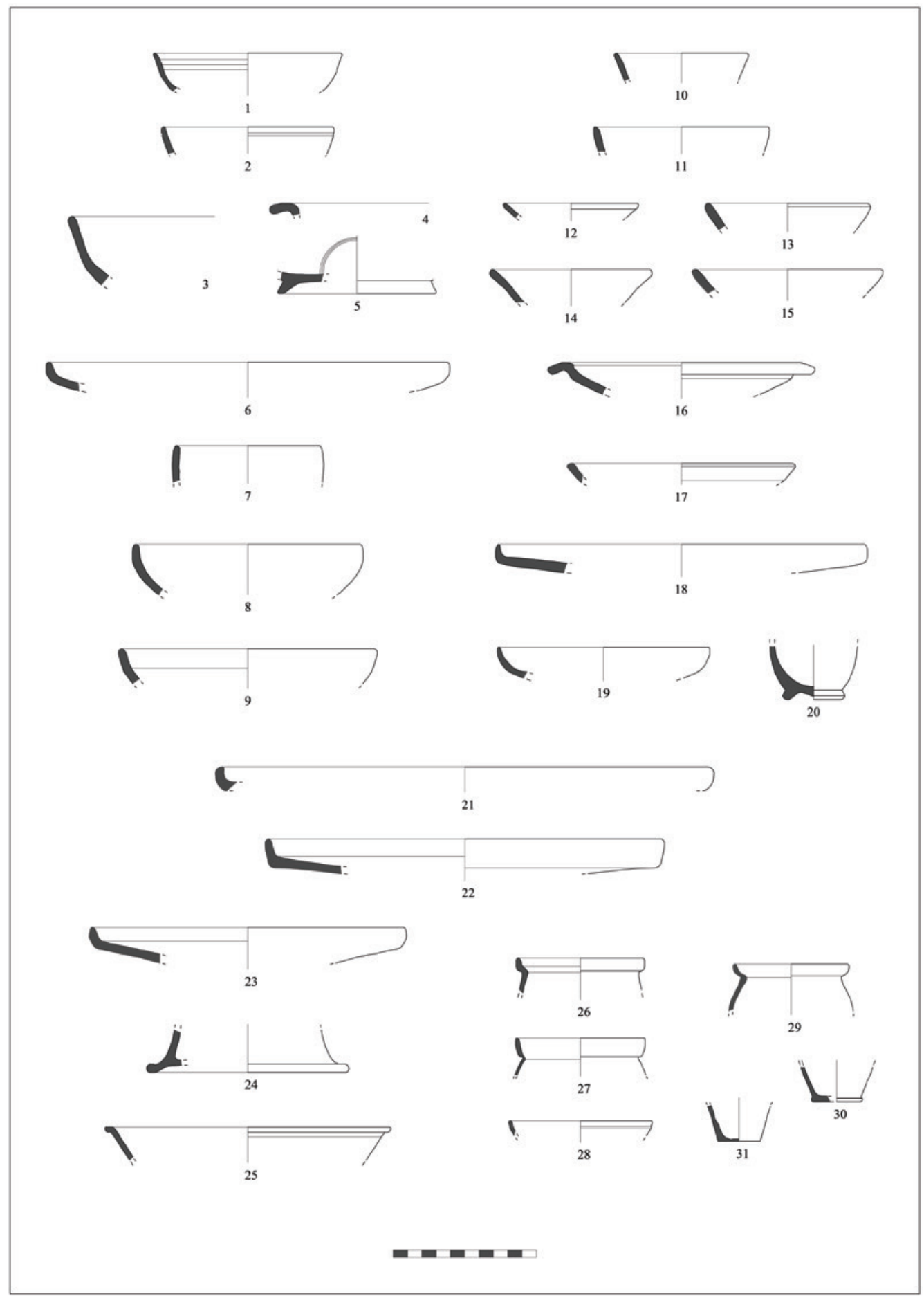

Figura 13. Vajilla de mesa itálica. Campaniense A: 1 (M. 3614); 2 (M. 3131); 3 (Lamb. 8 b); 4 (Lamb. 6); 5 (Lamb. 1); 6 (Lamb. 5); 7 (Lamb. 27 a-b); 8 (Lamb. 27 b); 9 (Lamb. 27 c); 10 y 11 (Lamb. 31 b); 12, 13 y 15 (Lamb. 33 b); 14 (Lamb. 38 a-b); 16 (Lamb. 36). Campaniense B: 17 (Lamb. 1); 18 (Lamb. 5); 19 (Lamb. 8 b); 20 (Pedroni 780). Campaniense B etrusca: 21 y 23 (Lamb. 5); 22 (Lamb. 7); 24 (Lamb. 3); 25 (Lamb. 8). Paredes finas: 26 (Mayet II-III); 27 (Mayet III); 28 (Mayet V); 29 (Mayet IV); 31 (Mayet I); 30 (Mayet I-III) 
y de borde bífido más marcado, de tal manera que parece consolidarse un repertorio adecuado a los hábitos de consumo romanizados que sin duda se imponen. Así pues, el repertorio de cocina de las últimas décadas del siglo I a.C. no depende ya tanto de la recepción de cerámicas italianas adecuadas a tal función, pues éstas han sido en mayor o menor grado sustituidas por formas directamente imitadas o bien inspiradas en los repertorios itálicos de cocina.

\section{Cerámica de barniz negro, lucernas y paredes finas}

También las producciones de barniz negro presentan un cambio notable en su morfología y procedencia en el tiempo que va desde los años finales del siglo II, momento a partir del cual su recepción es masiva, hasta las últimas producciones de fines del siglo I a.C. (fig. 13: 1-25). Las cerámicas campanienses de la clase A son prácticamente las únicas representadas en las UU.EE. 371 y 372 de Abades, donde están acompañadas de un fragmento de copa megárica con decoración de círculos concéntricos. Se documentan principalmente las formas Lamb. 8b, Lamb. 27 a-b, Lamb. 33 y y Lamb. 36, que corresponden en su totalidad al repertorio medio de la clase A.

Las mismas formas 8b, 27b, 33b y 36 se registran en la Cuesta del Rosario (aunque en un contexto "reconstruido" a partir de la tipología del material), a las que hay que añadir la Lamb. 5 y 5/7, también en Campaniense A, y un bol de la forma 1 en Campaniense B.

Campanienses A y B conviven igualmente en Argote de Molina pero, al contrario que en la Cuesta del Rosario, con un claro predominio de las campanienses de la clase B $(42,55 \%$ y $57,45 \%$ respectivamente, con un $36,6 \%$ de Campanienses B de procedencia etrusca), siendo el repertorio de ambas clases muy variado (Lamb. 5; 5-7; 6; 27 a, b y c; 33 b; 34 b y 36 en Campaniense A y Lamb. 1, 3, 5, 6, 7, 8, 8b, 10 y Pedroni 700, en Campaniense B). En la Cuesta del Rosario, el nivel VI, del tercio central del siglo I a.C. (con las dudas pertinentes), presenta sólo ejemplares de la clase B (Lamb. 1 y 3), mientras que en la calle Alemanes se documentan sobre todo formas terminales de las Campanienses B tardías, con un repertorio muy estandarizado y compuesto por las formas de Lamboglia 1, 3, 4, 5, 8 y 33b. Estas producciones terminales se caracterizan por un barniz poco denso y no muy oscuro con irisaciones plateadas, bien distribuido, excepto en los fondos, que presentan chorreones y zonas en reservas en la pared exterior del anillo basal.
Aparecen, además, piezas con un disco rojo o castaño en el interior del fondo e incluso piezas completamente cubiertas por un barniz rojo brillante en lugar de negro (Lamb. 1).

Las lucernas son escasas, pero no faltan ejemplares de las formas Ricci A (siglos III-II a.C. en Cuesta del Rosario), Ricci E y Dressel 1B (siglo I a.C. en la Cuesta del Rosario), así como Ricci G, Ricci H y Dressel 2 en Argote de Molina. En Fabiola, en época tempranoaugustea, predominan ya las lucernas de volutas: Dressel 3 y $9 b$.

Las formas de paredes finas mayoritariamente documentadas son los cubiletes, de las formas Mayet I para fines del siglo II a.C. y Mayet II, III, IV y Marabini IV para el siglo I a.C., lo que coincide con el desarrollo cronológico de los vasos de paredes finas en época tardorrepublicana (fig. 13: 26-30). La forma Mayet II ya está presente en contextos del último cuarto del siglo II, siendo frecuente en los del primer cuarto del I a.C. y manteniéndose en circulación hasta el último cuarto de esta centuria, mientras que la forma III no se generaliza hasta las primeras décadas del siglo I a.C.

\section{CONCLUSIONES}

Este lapso de tiempo se puede subdividir en tres fases, atendiendo a la procedencia y composición de los repertorios cerámicos.

\section{Fase I (finales siglo IV-III a.C.)}

Este periodo viene marcado por la llegada masiva de ánforas púnicas procedentes del área del Estrecho, especialmente variantes evolucionadas del tipo MP-A4 (T-11.2.1.3 y T-12.1.1.1 en la tipología de Ramón) y posteriormente las T-8.2.1.1, destinadas ambas al transporte de salazones y salsas de pescado. Junto a ellas comienzan a aparecer, ya en el tránsito al siglo III, los primeros contenedores producidos en las campiñas de Jerez y El Puerto de Santa María (Ramón T-8.1.1.2 ¿y T-8.2.1.1?), donde se comercializan básicamente productos agropecuarios, aceite y vino sobre todo.

La distribución de ánforas de procedencia púnica en la antigua Spal no parece traslucir cambios en los hábitos de consumo con respecto al periodo anterior, pues los productos son esencialmente los mismos (salazones, aceite y vino, principalmente). En todo caso, refleja la intensificación de las relaciones comerciales con el área del Estrecho y muy especialmente con la campiña 
gaditana, que se convierte ahora en uno de los mayores proveedores de productos agrícolas de las ciudades turdetanas. El proceso a través del cual se genera este cambio en las importaciones sigue siendo una incógnita, pero resulta llamativo comprobar cómo la distribución de contenedores púnicos parece dibujar a grandes rasgos el área de influencia comercial gaditana, en el cual se incluyen tanto los centros y las factorías de la costa atlántica suroccidental de Iberia (Huelva, La Tiñosa, Castro Marim, Tavira, etc.), como el interior del antiguo estuario del Guadalquivir (Ilipa Magna, Cerro Macareno, Itálica y $S p a l$ ), a lo que habría que sumar el litoral norteafricano, con Lixus y Kouass como ejemplos más representativos (García y Ferrer 2010: 371-372).

En estos momentos la composición de los repertorios comunes parece no variar. Se siguen produciendo los mismos recipientes, con o sin decoración pintada, heredados en su mayoría de la matriz orientalizante. Se generalizan, no obstante, algunas formas que si bien ya se conocían previamente, alcanzan ahora su máxima difusión. Nos estamos refiriendo a los cuencos-lucerna, los “vasos para beber" y algunas variantes de urnas globulares o bitroncocónicas con asas laterales o con un resalte en los hombros. En cualquier caso, se trata de una evolución a escala regional de los repertorios domésticos, que continuará durante las siguientes centurias, y que no implica cambio alguno en las formas de servicio y consumo de alimentos. Por su parte, la vajilla de lujo tipo "Kouass" es minoritaria, como ya hemos tenido oportunidad de comprobar, ciñéndose por lo general a las formas II y IX de Niveau (2003), que reproducen $\sin$ grandes variaciones dos formas más que habituales en el repertorio común, como es el plato de pescado y el cuenco o copa.

Parece existir una correspondencia entre la escasa presencia de importaciones áticas en algunos centros del Bajo Guadalquivir y la poca representatividad de las imitaciones gaditanas, que podría estar relacionado con la propia estructura de la sociedad turdetana, donde la vajilla de lujo no juega un papel tan relevante como bien de prestigio si lo comparamos, por ejemplo, con el mundo ibérico. En cualquier caso, la pobreza de las importaciones no implica necesariamente la ausencia de formas de consumo ritualizadas, en las que participaría también -y en algunos casos exclusivamente- la cerámica común pintada (Jiménez y García 2006: 143), como tampoco parece implicar unas prácticas o usos diferenciados en las ocasiones en que la vajilla de lujo aparece asociada a contextos domésticos.

Lo mismo se puede decir de la cerámica de cocina. El recipiente estrella para la preparación de alimentos sigue siendo la olla, que en estos momentos se fabrica ya a torno, reproduciendo a grandes rasgos la misma morfología de sus predecesoras de los siglos VI y V a.C. (Ferrer y García 2008: 211). Precisamente en el siglo IV a.C. se difunde, como hemos visto, la olla con borde engrosado y hombros pronunciados, característica del menaje doméstico turdetano incluso después de la conquista romana (García y González 2007: 559). Sólo ocasionalmente encontramos recipientes de tradición (o procedencia) gaditana, como es el caso de un fragmento de olla de paredes delgadas y borde triangular (GDR 12.3.1) hallado en el nivel 26 de Argote de Molina, destinada igualmente a la cocción.

La única novedad en este periodo es la generalización del mortero de tradición púnica, cuyo uso se extiende hacia el Bajo Guadalquivir a finales del siglo IV a.C. Aunque a día de hoy se desconoce el cometido exacto de este recipiente, su morfología y sus características técnicas permiten asociarlo verosímilmente con la función de triturar y amasar los ingredientes, probablemente cereales y legumbres, destinados a la elaboración de purés o gachas. La rápida propagación de esta forma a las ciudades de la Turdetania y su temprana imitación en talleres locales sí pudieron estar relacionados, en este caso, con la adopción de nuevas formas de preparar los alimentos y la difusión de nuevos platos que remiten en última instancia al ámbito centromediterráneo.

\section{Fase II (siglo II a.C.)}

A finales del siglo III, coincidiendo con la ocupación bárquida, se intensifican las relaciones con el mundo púnico. Prueba de ello son las ánforas de fabricación norteafricana que, a través de Cádiz, arribaron al puerto de Sevilla. Es el caso de los ejemplares de Mañá D (T-5.2.3.1) y Mañá C2 (T-7.2.1.1) documentados en la calle Argote de Molina, relacionados respectivamente con la comercialización de vino y de salsas de pescado procedentes de la zona de Cartago. No obstante, su presencia puede considerarse cuanto menos marginal, sobre todo si la comparamos con los especimenes registrados en la propia Cádiz (Muñoz 1987: 475-476; Niveau de Villedary 2002-2003: 274-275) o en Castillo de Doña Blanca (Niveau de Villedary 1999: 134-135). Las ánforas más numerosas siguen siendo las producciones locales de la forma D de Pellicer, así como los contenedores de fabricación gaditana, especialmente el tipo 8.2.1.1, al que habría que sumar los primeros ejemplares del tipo 9.1.1.1, vinculados ya en 
exclusiva al transporte de salazones de pescado (de Frutos y Muñoz 1996: 140).

El final de la II Guerra Púnica y la victoria romana no supuso el cese de estas importaciones, sino todo lo contrario. En estos momentos se potenciará la producción y comercialización de salazones, vino y aceite no sólo en el entorno de Cádiz, sino también en el área del Estrecho y la costa onubense (Ferrer 2004; 2007). Ello no fue impedimento para que comenzara a introducirse en estos mercados el vino campano, envasado en ánforas grecoitálicas primero y posteriormente en Dressel 1, ya desde mediados del siglo II a.C. Sin embargo, no se produjo cambio alguno en las formas de servicio y consumo de bebidas. Las copas y boles de cerámica campaniense o megárica que aparecen en algunos contextos, al igual que las páteras de barniz negro, sólo vinieron a sustituir circunstancialmente formas similares producidas localmente a torno, como ya ocurriera en la centuria anterior con la vajilla tipo "Kouass".

Recientemente se ha señalado, sin embargo (Pérez Ballester 2008), que las formas de cerámica campaniense indican cambios de los patrones de consumo relacionados no sólo con el vino, sino también con otros alimentos cuya consistencia (líquida o semilíquida) estaría tras la transformación de un repertorio de importación basado fundamentalmente en los cuencos a otro en el que prevalecen los platos y las fuentes (supra). Ciertamente, una de las características del repertorio de mesa turdetano es el predominio de los cuencos sobre los platos, los cuales, si bien suelen estar presentes en todos los contextos, son siempre cuantitativamente menos representativos (fig. 4).

La cerámica de cocina no acusa grandes novedades con respecto a la del siglo III, salvo la incorporación eventual de morteros y cazuelas de tradición centromediterránea. Aunque estas últimas se encuentran presentes en Cartago desde el siglo IV, su difusión por las costas peninsulares no se iniciará hasta finales del siglo III, coincidiendo precisamente con la expansión bárquida. Se trata de un recipiente muy especializado destinado con toda probabilidad a la fritura (Guerrero 1995: 62), si bien no se descarta tampoco la cocción de alimentos con poca agua. La aparición esporádica del mortero cartaginés no parece implicar cambio alguno en el uso -triturar y amasar- que hemos propuesto para los especimenes peninsulares. De hecho, se ha planteado incluso la posibilidad de que fuera en estos recipientes donde se elaborara la llamada Puls Punica (Martín y Roldán 2000: 1616), consistente, según Catón (Agr., 85), en una especie de gachas o puré realizado con harina de trigo y legumbres que podía mezclarse con agua, queso fresco, miel o huevos. Ambos recipientes se encuentran ampliamente representados en los contextos domésticos y funerarios de la Gadir púnica (Niveau de Villedary 20022003), aunque son frecuentes sobre todo en el litoral mediterráneo y las Baleares. En cualquier caso, la proliferación de imitaciones locales (Sáez 2005: 162-163) es indicativa del éxito que adquieren estos nuevos hábitos culinarios en las comunidades púnicas del sur de Iberia, cuyos usos se extienden capilarmente hacia el interior.

Resulta paradójico que sea precisamente tras la derrota de Cartago y la posterior conquista romana cuando el empleo de cazuelas con tapadera, una herencia genuina de la cocina cartaginesa, se extienda hacia el interior de Turdetania. Sin embargo, su presencia en la ciudad de Sevilla tampoco deja de ser testimonial, sobre todo si lo comparamos con el resto del menaje de cocina recuperado, formado esencialmente por ollas y morteros de producción local. Estas circunstancias se repiten en otras localidades del antiguo estuario del Guadalquivir, como Itálica, Cerro Macareno o la propia Ilipa Magna, mucho menos permeables a las innovaciones gastronómicas que las poblaciones costeras como Gadir o Doña Blanca. Habrá que esperar a finales del siglo II o inicios del I a.C. para que los cambios en la forma de preparar y cocinar los alimentos se generalicen entre el resto de la población.

La cerámica común parece continuar las tendencias marcadas en la centuria anterior: simplificación de la decoración en la mayoría de los recipientes, mejora de las pastas y mantenimiento de la variedad de formas. Como novedad desde el punto de vista morfológico sólo cabe reseñar la aparición de nuevas variantes en algunos de los tipos más comunes, como es el caso de los lebrillos y las urnas globulares. A partir del siglo II a.C. los lebrillos adoptan perfiles más abiertos, con paredes más gruesas y bordes muy desarrollados, que adquieren ahora una sección ovoidal, cuadrangular o almendrada (Pellicer y otros 1983: 93). De hecho, será esta variante la que pase a la cerámica común romana, manteniéndose a grandes rasgos la misma forma y probablemente también la misma función durante los primeros siglos de nuestra Era. Por lo que respecta a las urnas, a finales del siglo II a.C. se extiende una nueva variante con el cuello más corto y cilíndrico que vendrá a reemplazar a los antiguos vasos de perfil acampanado. Como hemos visto, los bordes son muy característicos, engrosados al exterior, con secciones de forma triangular o trapezoidal, redondeados y en ocasiones ligeramente caídos formando una leve pestaña.

La única novedad en el servicio de mesa es la incorporación circunstancial de jarras de tradición púnica. 
Se trata de un elemento habitual en Cádiz (Sáez 2005: 160), Doña Blanca (Niveau de Villedary y Ruiz Mata 2000: 897, fig. 5) o la campiña de Jerez (González 1987: 94), que se encuentra presente también en las factorías del otro lado del Estrecho, como es el caso de Kouass (Kbiri Alaoui 2007: 141, fig. 119). No obstante, una vez más su escasa concurrencia en los contextos domésticos de la ciudad de Sevilla no nos permite hablar de un uso generalizado de este elemento, ni de la adopción de un menaje específico para el servicio de bebidas en estos momentos. Como puede apreciarse en los distintos conjuntos analizados, se mantienen los mismos repertorios y los mismos patrones de uso que hemos venido observando desde mediados del siglo IV, lo que permite adivinar una actitud sumamente conservadora en lo que se refiere también a las pautas de servicio y consumo de alimentos.

Por último, la introducción de motivos decorativos de tradición ibérica puede relacionarse con una reactivación del comercio con Andalucía Oriental y las costas del Levante peninsular desde finales del siglo III a.C. pero, sobre todo, durante los inicios de la presencia romana (Escacena 1987: $1083 \mathrm{ss).} \mathrm{En} \mathrm{ello} \mathrm{tuvo} \mathrm{mucho}$ que ver la pacificación de la región y, posteriormente, la reorganización de las redes comerciales, una vez diluidas las áreas de influencia respectivas de Gadir y Cartago (Ferrer 1998: 44-47), ahora bajo control romano. Por su parte, la ocupación militar de Turdetania, la paulatina transformación de las estructuras territoriales y la puesta en explotación de los distritos mineros de Sierra Morena por parte de colonos itálicos (Blázquez y otros 2002) debió haber favorecido la circulación de personas y mercancías a lo largo y ancho de la depresión del Guadalquivir, un fenómeno que se nos muestra especialmente evidente a finales del siglo II a.C. (Chaves 1994). Podría decirse que la "iberización" de la Turdetania es un fenómeno tardío y en cualquier caso debió tratarse más de una cuestión de modas y estilos que de una asimilación generalizada de hábitos o costumbres del área ibérica.

\section{Fase III (finales del siglo II - siglo I a.C.)}

En el siglo I a.C. las importaciones del ámbito púnico se ciñen ya exclusivamente a ánforas, sobre todo los envases producidos en la bahía de Cádiz y destinados al transporte de salazones y salsas de pescado. Nos estamos refiriendo al tipo 9.1.1.1 de Ramón y a las ánforas Mañá C2b (T-7.4.3.3), de tradición norteafricana (véase Sáez 2008a; 2008b). Ambas conviven hasta inicios del principado de Augusto (Ramón 1995: 213), cuando son sustituidas totalmente por las ánforas Dressel 7/11. Las ánforas locales se encuentran una vez más representadas por la forma $\mathrm{D}$ de Pellicer, que adopta ahora el perfil característico de las últimas producciones, con labios de tendencia horizontal, indiferenciados ya del cuerpo, y una reducción en la abertura de la boca, como puede comprobarse en los ejemplares procedentes del nivel 20 de la calle Argote de Molina (Campos 1986: fig. 45).

La cerámica de cocina sigue estando protagonizada por las ollas de fabricación local, que ahora adquieren una morfología particular, caracterizada por un labio vuelto, de sección triangular, y una mayor altura. Junto a ellas aparecerán también algunas ollas de importación correspondientes al tipo Vegas 2 (Itálica 3C). Los morteros, por su parte, comienzan a imitar localmente formas de tradición itálica, principalmente el tipo Emporiae 36.2. Ambos recipientes parecen mantener, no obstante, la misma función en la preparación de alimentos. Asimismo, las cazuelas de origen centromediterráneo son sustituidas por sartenes y platos de fabricación itálica, como es el caso de las formas Celsa 84.13596, Celsa 79/28, Vegas 14 y Luni 1, destinados respectivamente a las funciones de freír y asar. La mayor frecuencia de estas formas, en detrimento de las ollas conforme avanza el siglo I a.C. debe interpretarse como consecuencia de la adopción progresiva de nuevos hábitos gastronómicos de origen itálico o centromediterráneo (supra).

Este mismo fenómeno parece subrayado por los cambios en el repertorio de barniz negro. Las cerámicas campanienses de fines del siglo II a.C. en Abades presentan un elenco de formas dominado por los boles y cuencos (formas 27, 28 y 33 de Lamboglia sobre todo), mientras que las páteras y los platos (formas Lamb. 1, $5,7 \ldots$ ) se convertirán en los protagonistas casi exclusivos del repertorio de la segunda mitad del siglo I a.C. (Alemanes), tras un período de transición a lo largo de la primera mitad del mismo siglo (Argote de Molina). También se produce un afianzamiento progresivo de las cerámicas campanienses del tipo B-oïde en detrimento de las producciones de la variante $\mathrm{A}$, que dominaban a fines de la segunda centuria antes de nuestra Era. A principios del siglo I las Campanienses B son ya mayoritarias en la ciudad, con una representación consistente de Campanienses B "verdaderas", mientras que ya a fines de siglo el predominio de las B-oïdes, en especial del taller o los talleres de Cales, es prácticamente absoluto.

La cerámica común se caracteriza ahora por presentar pastas más claras, con una cocción predominantemente 
oxidante y engobes espesos de color crema. La pintura, reducida ya a la mínima expresión, se limita a líneas delgadas de coloración vinosa situadas en el borde o el cuerpo de las grandes urnas. Diferente es el caso de los lebrillos de borde engrosado, que pueden incorporar eventualmente una decoración bastante original, a base de trazos sinuosos en el interior y reticulados en el fondo. Por lo demás, se mantienen junto a estas producciones los tipos principales del repertorio turdetano, generalmente sin decorar, que perdurarán en su mayoría hasta época augustea o augusto-tiberiana. Nos estamos refiriendo a las urnas globulares de cuello corto, platos de labio engrosado, cuencos y lebrillos. Los cuencos lucernas y los pequeños vasos de perfil en S serán definitivamente sustituidos a lo largo del siglo I a.C. por las lucernas de tradición itálica y la cerámica de paredes finas.

Se pueden definir también ámbitos de predominio formal romanizado en las cerámicas comunes, tanto en los repertorios de cocina (ollas, cazuelas de borde bífido, platos, platos-tapadera, sartenes) como en los de preparación de alimentos (morteros) o servicio de mesa (jarras). Morteros y jarras adquieren a lo largo de la segunda mitad del siglo I a.C. las características que serán habituales en época augustea y julio-claudia temprana. Los morteros desarrollan una tipología regional muy característica dominada por dos formas principales, derivadas respectivamente de los tipos itálicos Emporiae 36.2 y Dramond 1. Las jarras se multiplican en versiones de cuello alto con o sin molduración en el borde, definiendo junto a las tazas con asas y a las pequeñas "ollas" de borde entrante horizontal un repertorio ya claramente romanizado. Éste cristalizará a lo largo del siglo I d.C. en el elenco julio-claudio de formas comunes (Huarte 2003), que apenas conserva ya trazas de las producciones de tradición indígena tan frecuentes todavía hacia el cambio de Era.

Un fenómeno similar puede, finalmente, señalarse para las ánforas. A lo largo del siglo I a.C. las producciones locales-regionales comienzan a tomar el relevo de las importaciones itálicas, y si en los contextos de fines del II-inicios del I a.C. son las vinarias Dressel 1A, B y C las protagonistas del registro anfórico, con el transcurso del siglo se van afianzando las importaciones del área gaditana (cuya presencia en la ciudad se remonta, no obstante, a los siglos V-IV a.C.), especialmente las tardopúnicas T-7.4.3.3 (fig. 9: 5-6) y T-9.1.1.1 (fig. 8: 6), las imitaciones de Dressel 1C (fig. 11: 1), y las romanizadas Dressel 7-11 arcaicas (fig. 11: 4-5), así como las ánforas olearias y vinarias del Guadalquivir. Entre éstas destacan las de morfología tradicional o turdetana, del tipo Pellicer D, que se fabrican junto a las formas romanizadas en alfares urbanos como los de Carmona hasta época de Augusto; y también las de morfología romanizada, desde las imitaciones de ánforas itálicas de las variantes A y B de Dressel 1 (fig. 11: 2), hasta las LC 67 (fig. 11: 13-14), Oberaden 83 (fig. 11: 16-17), Ovoide 4 del Guadalquivir (Almeida 2008) (fig. 11: 19-20), ánforas de fondo plano del tipo Urceus (Morais 2005, e.p.) (fig. 11: 22-24) y Haltern 70 (fig. 11: 7-8). En conjunto, se trata de un repertorio cuyos perfiles se van conociendo cada vez mejor y que suponen un primer momento en la definición de las tipologías anfóricas del Guadalquivir, ya constituidas como tales, como sucede con las formas de cerámica común, en época julio-claudia plena, esto es, hacia mediados del siglo I d.C.

\section{Epílogo. El tránsito hacia los repertorios cerámicos imperiales}

Aunque de momento apenas contamos con contextos claramente augusteos en la ciudad de Sevilla, en el Bajo Guadalquivir el cambio de Era viene definido por una cierta continuidad en los repertorios comunes de tradición turdetana, por la cristalización del repertorio anfórico bético y por la generalización de la vajilla fina de mesa, con la introducción masiva de la TSI y sus imitaciones locales (no sólo cerámica tipo Peñaflor), cuya caracterización y estudio es una de las tareas pendientes para la investigación futura. Para terminar, un aspecto que está recibiendo en los últimos años una especial atención es la formalización del repertorio común de cocina y de mesa cuya composición se encuentra totalmente definida en las producciones del alfar de Las Cinco Llagas de Sevilla (Huarte 2003), hacia mediados del siglo I d.C., un momento en el que la tipología es totalmente romana y la cerámica común pintada ha desaparecido completamente.

\section{BIBLIOGRAFÍA}

ARRUDA, A.M. (2001): "Importações púnicas no Algarve: cronología e significado", Os punicos no Extremo Occidente. Actas do Coloquio Internacional: 69-98. Lisboa.

ARRUDA, A.M.; VIEGAS, C.; BARGÃO, P. y PEREIRA, R. (2006): “A importação de preparados de peixe em Castro Marim: da Idade do Ferro à Época Romana", Simposio Internacional Produção e Comércio de Preparados Piscícolas durante 
a Proto-história e a Época Romana no Ocidente da Península Ibérica. Homenagem a Françoise Mayet, Setúbal Arqueológica 13: 153-176.

ASENSIO i VILARÓ, D. (2001-2002): “Cerámicas de cocina cartaginesas en contextos ibéricos de la costa catalana", El Mundo Púnico. Religión, Antropología y cultura material, Estudios Orientales 5-6: 305-318.

BANDERA ROMERO, M ${ }^{\mathrm{a}}$.L. DE LA y FERRER ALBELDA, E. (2002): "Secuencia estratigráfica tartesia y turdetana de Vico (Marchena, Sevilla)", Homenaje al Profesor Pellicer. Spal 11: 121-149. http://dx.doi.org/10.12795/spal.2002.i11.06

BATS, M. (1988): Vaisselle et alimentation à Olbia de Provence: (v. 350 -v- 50 av-J.-C): modéles culturels et catégories céramiques. Paris.

BELTRÁN FORTES, J.; GONZÁLEZ ACUÑA, D. y ORDÓÑEZ AGULLA, S. (2005): “Acerca del urbanismo de Hispalis. Estado de la cuestión y perspectivas", Mainake XXVII: 61-88.

BLÁZQUEZ MARTÍNEZ, J.Mª; DOMERGUE, C. y SILLIÈRES, P. (2002): La mine et le village minière antique de La Loba (Fuenteobejuna, province de Cordoube, Espagne). Burdeos.

CAMPOS CARRASCO, J. (1986): Excavaciones arqueológicas en la ciudad de Sevilla. El origen prerromano y la Hispalis romana. Sevilla.

CAMPOS CARRASCO, J.; VERA REINA, M. y MORENO MENAYO, Mª.T. (1988): Protohistoria de la ciudad de Sevilla. El corte estratigráfico de San Isidoro 85-6, Monografías de Arqueología Andaluza 1, Sevilla.

CARRETERO POBLETE, P. (2004): "Las producciones cerámicas de ánforas tipo 'Campamentos $\mathrm{Nu}$ mantinos’ y su origen en San Fernando (Cádiz): los hornos de Pery Junquera", Actas del Congreso Internacional FIGLINAE BAETICAE. Talleres alfareros y producciones cerámicas en la Bética romana (ss. II a.C. - VII d.C.), BAR International Series 1266: 427-440. Oxford.

- (2007): Agricultura y Comercio Púnico-Turdetano en el Bajo Guadalquivir. El inicio de las explotaciones oleícolas peninsulares (siglos IV-II a.C.), BAR International Series 1703, Oxford.

CERVERA POZO, L.; DOMÍNGUEZ BERENJENO, E.L. y GARCÍA VARGAS, E. (2007): "Estructuras de época romana en c/ Santa Verania no 22", I Congreso de Historia de Alcalá del Río. Ilipa Antiqua. De la Prehistoria a la Época Romana: 295-310. Sevilla.

CHAVES TRISTÁN, F. (1994): “Indigenismo y romanización desde la óptica de las amonedaciones hispanas de la Ulterior", Habis 25: 107-120.
DE FRUTOS REYES, G. y MUÑOZ VICENTE, A. (1996): "La industria pesquera y conservera púnico-gaditana: balance de la investigación. Nuevas perspectivas", Spal 5: 133-165. http://dx.doi. org/10.12795/spal.1996.i5.07

ESCACENA CARRASCO, J.L. (1987): Cerámicas a torno pintadas andaluzas de la segunda Edad del Hierro (Tesis Doctoral microfilmada, Universidad de Cádiz). Cádiz.

- (2000): La arqueología protohistórica del sur de la Península Ibérica. Historia de un río revuelto. Madrid.

ESCACENA CARRASCO, J.L. y BELÉN DEAMOS, M. (1994): "Sobre las necrópolis turdetanas", Homenaje al Profesor Presedo: 237-265. Sevilla.

ESCRIVÁ TORRES, V.; MARÍN JORDÁ, C. y RIBERA I LACOMBA, A. (1992): "Unas producciones minoritarias de barniz negro en Valentia durante el s. II a. JC.", Estudios de Arqueología Ibérica y Romana: homenaje a Enrique Pla Ballester: 443468. Valencia.

ESCUDERO CUESTA, J.; LORENZO MORILLA, J. y VERA REINA, M. (1990): "Excavaciones en la calle Fabiola ${ }^{\circ}$ 8. Sevilla”, $A A A / 1987$, vol. III: 591-594.

ESCUDERO CUESTA, J. y VERA REINA, M. (1991): "Excavaciones arqueológicas en la calle Mármoles n ${ }^{\circ}$ 9. La problemática del sector", $A A A / 1988$, vol. III: 407-410.

FERNÁNDEZ CHICARRO, C. (1952): "El tesoro de la Cuesta del Rosario de Sevilla", Numario Hispánico 1 (1-2): 63-70.

FERNÁNDEZ GÓMEZ, F.; CHASCO VILA, R. y OLIVA ALONSO, D. (1979): “Excavaciones en El Cerro Macareno. La Rinconada. Sevilla (Cortes EF-G. Campaña 1974)", NAH 7: 9-93.

FERRER ALBELDA, E. (1995): Los púnicos en Iberia: Análisis historiográfico y arqueológico de la presencia púnica en el sur de la Península Ibérica (Tesis Doctoral inédita, Universidad de Sevilla), Sevilla.

- (1998): "Suplemento al mapa paleoetnológico de la Península Ibérica: los púnicos de Iberia", RSF XXVI (1): 31-54.

- (2004): "Sustratos fenicios y adstratos púnicos: los bástulos entre el Guadiana y el Guadalquivir", III Congreso Español de Antiguo Oriente Próximo, Huelva Arqueológica 20: 281-298.

- (2007): "El territorio de la ciudad bástulo-púnica de Baesippo", Las ciudades fenicio-púnicas en el Mediterráneo Occidental: 282-314. Almería.

FERRER ALBELDA, E. y GARCÍA FERNÁNDEZ, F.J. (2002): "Turdetania y turdetanos: contribuciones a una problemática historiográfica y 
arqueológica", Colonizadores e indigenas en la Península Ibérica. Mainake XXIV: 133-151.

- (2007): "Primeros datos sobre la Ilipa turdetana", I Congreso de Historia de Alcalá del Río. Ilipa Antiqua. De la Prehistoria a la Época Romana: 103130. Sevilla.

- (2008): "La cerámica turdetana", Cerámicas hispanorromanas. Un estado de la Cuestión: 202-219. Cádiz.

FERRER ALBELDA, E.; GARCÍA FERNÁNDEZ, F.J. y GONZÁLEZ ACUÑA, D. (e.p.): "El comercio púnico en Spal", VI Congresso Internacional de Estudos Fenício Punicos (Lisboa, 2005).

GARCÍA FERNÁNDEZ, F.J. (2007): "Etnología y etnias de la Turdetania en época prerromana", $\mathrm{Cu}$ PAUAM 33: 117-143.

- (2009): "La colonización agrícola de las terrazas del Guadalquivir en época romana: el caso del arroyo de Las Culebras (Dos Hermanas, Sevilla)", Estudios de Prehistoria y Arqueología en homenaje a Pilar Acosta Martínez: 483-504. Sevilla.

GARCÍA FERNÁNDEZ, F.J. y GONZÁLEZ ACUÑA, D. (2007): "Secuencias estratigráficas y contextos culturales de la Sevilla prerromana", V Congreso de Historia de Carmona. Los orígenes de la ciudad: la Carmona Protohistórica: 525-566. Carmona.

GARCÍA FERNÁNDEZ, F.J. y FERRER ALBELDA, E. (2010): "Das turdetanische Emporion Spal. Der punische Handelsverkehr im vorrömischen Sevilla (5. - 2. Jh. V. Chr.)", MM 52: 335-374.

GARCÍA VARGAS, E. (2009): "Las ánforas republicanas de Hispalis (Sevilla) y la 'cristalización' del repertorio provincial”, Estudios de Prehistoria y Arqueología en homenaje a Pilar Acosta Martínez: 437-464. Sevilla.

GARCÍA VARGAS, E.; MORA DE LOS REYES, M. y FERRER ALBELDA, E. (1989): "Estudios sobre cerámicas ibéricas andaluzas: Montemolín (Marchena, Sevilla)", Habis 20: 217-243.

GONZÁLEZ ACUÑA, D. (2005): "Imágenes de Hispalis. De la visión mítica al conocimiento científico", La Catedral en la ciudad (I). Sevilla, de Astarté a San Isidoro: 59-90. Sevilla.

GONZÁLEZ RODRÍGUEZ, R. (1987): “Excavaciones de urgencia en el Cerro Naranja (Jerez de la Frontera, Cádiz)", $A A A / 1985$, vol. III: 90-96.

GUERRERO AYUSO, V.M. (1995): “La vajilla púnica de usos culinarios", $R S F$ XXIII (1): 61-99.

JIMÉNEZ FLORES, A.M y GARCÍA FERNÁNDEZ, F.J. (2006): "In vino humanitas (y II): vino y cultura en la Turdetania prerromana", Habis 37: 125-144.
JIMÉNEZ SANCHO, A. (2002): "Excavación en c/ Abades 41-43 (Sevilla); del siglo III a.C. al siglo IV", Romula 1: 125-150.

JIMÉNEZ SANCHO, A.; GARCÍA VARGAS, E.; GARCÍA FERNÁNDEZ, F.J. y FERRER ALBELDA, E. (2006): “Aportación al estudio de la Sevilla prerromana y romano-republicana. Repertorios cerámicos y secuencia edilicia en la estratigrafía de la calle Abades 41-43”, Spal 15: 281-311. http://dx.doi.org/10.12795/spal.2006.i15.15

KBIRI ALAOUI, M. (2007): Revisando Kuass (Asilah, Marruecos). Talleres cerámicos en un enclave fenicio, púnico y mauritano, Sagvntvm Extra 7, Valencia.

LANCEL, S. (1987): "La céramique punique d'époque hellénistique", Céramiques hellénistiques et romaines II: 99-137. París.

LUZÓN NOGUÉ, J.Ma . (1973): Excavaciones en Itálica. Estratigrafia en el Pajar de Artillo. EAE 78. Madrid.

MARTÍN CAMINO, M. y ROLDÁN BERNAL, B. (2000): "Cerámica de cocina de importación en la Cartagena púnica: los morteros y grandes platos. Siglo III a.C.", Actas del IV Congreso Internacional de EStudios Fenicios y Púnicos, vol. IV: 1615-1623. Cádiz.

MORAIS, R. (2004): “Os almofarizes béticos em Bracara Augusta", Actas del Congreso Internacional FIGLINAE BAETICAE. Talleres alfareros y producciones cerámicas en la Bética romana (ss. II a.C. - VII d.C.), BAR International Series 1266: 567-570. Oxford.

MUÑOZ VICENTE, A. (1987): "Las ánforas prerromanas de Cádiz (informe preliminar)”, $A A A / 1985$, vol. II: 471-478.

NIVEAU DE VILLEDARY Y MARIÑAS, A.Mª (1999): “Ánforas turdetanas, mediterráneas y púnicas del s. III del Castillo de Doña Blanca (El Puerto de Santa María, Cádiz)", XXIV CNA: 133-138. Cartagena.

- (2001-2002): "La cerámica púnico-gaditana del s. III a.C. El uso de la vajilla en el ámbito funerario y ritual de la necrópolis", El Mundo Púnico. Religión, Antropología y cultura material, Estudios Orientales 5-6: 267-297.

- (2002): "Las ánforas turdetanas del tipo Pellicer-D. Ensayo de clasificación", Homenaje al Profesor Pellicer, Spal 11: 233-252. http://dx.doi.org/10.12795/ spal.2002.i11.12

- (2003): Cerámicas gaditanas "tipo Kuass”. Madrid.

- (2006): "Banquetes rituales en la necrópolis púnica de Gadir”, Gerión 24 (1): 35-64.

NIVEAU DE VILLEDARY Y MARIÑAS, A.M ${ }^{\mathrm{a}}$. y RUIZ MATA, D. (2000): "El poblado de Las 
Cumbres (Castillo de Doña Blanca): urbanismo y materiales del s. III a.C.", Actas del IV Congreso Internacional de Estudios Fenicios y Púnicos, vol. III: 893-903. Cádiz.

ORTIZ NAVARRETE, A. y CONLIN HAYES, E. (e.p.): "Actividad arqueológica preventiva en c/ Doctor Fleming 13-15 de Carmona (Sevilla)", AAA/2007.

PELLICER CATALÁN, M. (1982): "Las cerámicas del mundo fenicio en el Bajo Guadalquivir: evolución y cronología según el Cerro Macareno (Sevi1la)", Phöinizier im Westen, Madrider Beiträge 8: 371-406. Mainz.

PELLICER CATALÁN, M.; BENDALA GALÁN, M. y ESCACENA CARRASCO, J.L. (1983): El Cerro Macareno. EAE 124. Madrid.

PÉREZ BALLESTER, J.; BORREDÁ, R. y CEBRIÁN, R. (1995): "La cerámica de cocina del s. I d.C. en Cartago Nova y sus precedentes republicanos", Ceràmica comuna romana d'època Alto-Imperial a la Peninsula Ibèrica. Estat de la questiò: 187-199. Ampurias.

PÉREZ BALLESTER, J. (2008): “La cerámica de barniz negro como mercancía, comercio y redistribución en Hispania", Comercio, redistribución y fondeaderos. La navegación a vela en el Mediterráneo. V Jornadas Internacionales de Arqueología Submarina: 209-220. Valencia.

PINTO, I.V. y MORAIS, R. (2007): “Complemento de comércio das ânforas: cerámica comum bética no território português", Cetariae 2005. Salsas y salazones de pescado en Occidente durante la Antigüedad. Actas del Congreso Internacional. BAR International Series 1686: 235-254. Oxford.

PRINCIPAL, J. (2000): "Vajillas de barniz negro de los campamentos del cerco numantinos (Garray, Soria)", La ceràmica de vernís negre dels segles II i I a.C.: centres productors mediterranis i comercialització a la Península Ibèrica: 269-279. Mataró.

- (2005): "Las cerámicas del círculo de la Campaniense B", Introducción al estudio de la cerámica romana: 47-61. Málaga.
RAMÓN TORRES, J. (1991): Las ánforas púnicas de Ibiza, Ibiza.

- (1995): Las ánforas fenicio-púnicas del Mediterráneo central y occidental, Barcelona.

RODERO RIAZA, E. (1991): "Las ánforas del Mediterráneo Occidental en Andalucía”, TP 48: 275-298.

RUIZ MATA, D. (1987): "La formación de la cultura turdetana en la Bahía de Cádiz a través del Castillo de Doña Blanca", Iberos. Actas de las I Jornadas sobre el Mundo Ibérico: 299-314. Jaén.

RUIZ MATA, D. y NIVEAU DE VILLEDARY Y MARIÑAS, A.Ma . (1999): "La zona industrial de Las Cumbres y la cerámica del s. III a.n.e. (Castillo de Doña Blanca-El Puerto de Santa María, Cádiz)", XXIV CNA: 125-131. Cartagena.

SÁEZ ROMERO, A.M. (2005): “Aproximación a la tipología de la cerámica común púnico-gadirita de los ss. III-II", Spal 14: 145-177. http://dx.doi. org/10.12795/spal.2005.i14.06

- (2008-a): La producción cerámica en Gadir en época tardopúnica (siglos-III/-I). BAR International Series, 1812 (2 vols.), Oxford.

- (2008-b): "La producción de ánforas en el área del Estrecho en época tardopúnica (siglos III-I a.C.)", Cerámicas hispanorromanas. Un estado de la cuestión: 635-659. Cádiz.

SÁEZ ROMERO, A.M.; DÍAZ RODRÍGUEZ, J.J. y MONTERO FERNÁNDEZ, R. (2004): “Acerca de un tipo de ánfora salazonera púnico-gadirita”, $\mathrm{Ha}$ bis 35: 109-133.

SERRANO RAMOS, E. (1995): "Producciones de cerámicas locales de la Bética", Ceràmica comuna romana d'època Alto-Imperial a la Peninsula Ibèrica. Estat de la questio: 227-249. Ampurias.

VENTURA MARTÍNEZ, J.J. (1985): “La cerámica campaniense de 'La Cuesta del Rosario' (Sevilla)”, AEspA 58: 41-68.

VERA REINA, M. (1987): “Aportación al conocimiento de la Sevilla antigua. Revisión de la excavación de la Cuesta del Rosario", Archivo Hispalense 215: 37-60.
FECHA DE ENTRADA: 12-07-2010

FECHA DE ACEPTACIÓN: 18-01-2011 